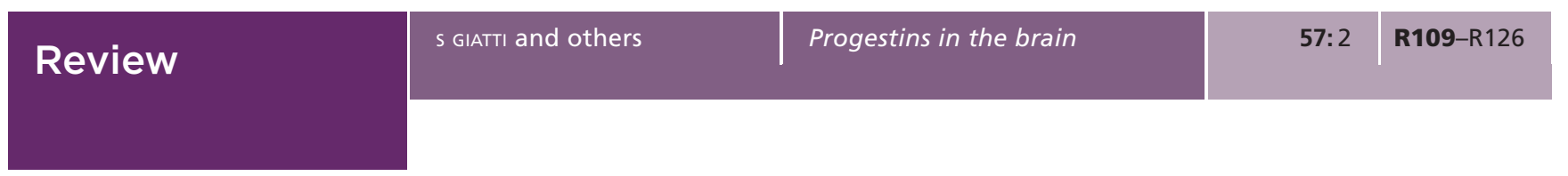

\title{
The other side of progestins: effects in the brain
}

\author{
Silvia Giatti, Roberto Cosimo Melcangi and Marzia Pesaresi
}

Department of Pharmacological and Biomolecular Sciences, Center of Excellence on Neurodegenerative Diseases, Università degli Studi di Milano, Milan, Italy

Correspondence should be addressed to R C Melcangi Email roberto.melcangi@unimi.it

\begin{abstract}
Progestins are a broad class of progestational agents widely differing in their chemical structures and pharmacological properties. Despite emerging data suggest that progestins, besides their action as endometrial protection, can also have multiple nonreproductive functions, much remains to be discovered regarding the actions exerted by these molecules in the nervous system. Here, we report the role exerted by different progestins, currently used for contraception or in postmenopausal hormone replacement therapies, in regulating cognitive functions as well as social behavior and mood. We provide evidence that the effects and mechanisms underlying their actions are still confusing due to the use of different estrogens and progestins as well as different doses, duration of exposure, route of administration, baseline hormonal status and age of treated women. We also discuss the emerging issue concerning the relevant increase of these substances in the environment, able to deeply affect aquatic wildlife as well as to exert a possible influence in humans, which may be exposed to these compounds via contaminated drinking water and seafood. Finally, we report literature data showing the neurobiological action of progestins and in particular their importance during neurodegenerative events. This is extremely interesting, since some of the progestins currently used in clinical practice exert neuroprotective and anti-inflammatory effects in the nervous system, opening new promising opportunities for the use of these molecules as therapeutic agents for trauma and neurodegenerative disorders.
\end{abstract}

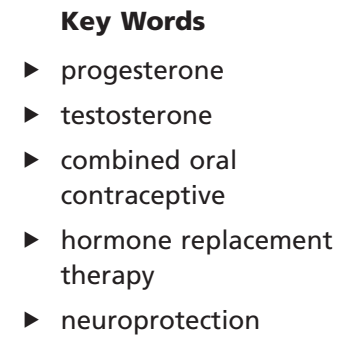

Journal of Molecular Endocrinology (2016) 57, R109-R126

\section{Introduction}

An extensively demonstrated progesterone (PROG), produced in peripheral glands as well as directly in the nervous system (Melcangi et al. 2008, Porcu et al. 2016), exerts important effects in the neuroendocrine control of reproduction and sexual behavior (Banks \& Freeman 1980, Barraclough et al. 1986, Skinner et al. 1998, Micevych \& Sinchak 2008, Schumacher et al. 2014), in the modulation of stress responsiveness and anxietylike behavior (Barbaccia et al. 2001, Schumacher et al. 2014) as well as in the regulation of adult neurogenesis
(Giachino et al. 2003, 2004, Wang et al. 2008), astroglial, and synaptic plasticity (Luquin et al. 1993, McEwen \& Woolley 1993, García-Segura et al. 1994, Murphy \& Segal 2000, Reyna-Neyra et al. 2002, Guerra-Araiza et al. 2007, Foy et al. 2008). Moreover, this steroid regulates the development of some neuronal types (i.e., Purkinje cells of the cerebellum) (Tsutsui et al. 2011), oligodendrocytes/Schwann cells (Jung-Testas et al. 1996, Ghoumari et al. 2005), as well as the myelination process (Chan et al. 2000,

Published by Bioscientifica Ltd 
Melcangi et al. 2005, Roglio et al. 2008, Schumacher et al. 2014).

These effects are mediated by an array of PROG receptors that include the classic nuclear progesterone receptors (PGR) and membrane-bound PROG receptors (Fig. 1). Two major isoforms of PGR are known: PGR-A and PGR-B, which are defined as ligand-activated transcription factors. Binding of PROG to these receptors produces multiple effects by regulating gene transcription (Brinton et al. 2008). PROG-induced nongenomic activity is mainly mediated by two different membrane-bound PROG receptor types: the seven-transmembrane progesterone adiponectin $\mathrm{Q}$ receptors (PAQR) and the single-transmembrane PGRs (Thomas 2008, Singh et al. 2013). The former are G protein-coupled membrane receptors and include three subtypes of receptors: PROG membrane receptors (mPGR) $\alpha, \beta$, and $\gamma$, also referred to as transmembrane PGRs $\alpha, \beta$, or $\gamma$ (7TMPR $\alpha, \beta, \gamma)$ and the two more recently identified subtypes mPGR $\delta$ and mPGRe (Pang et al. 2013, Hossain et al. 2015). When bound to its ligand, these receptors block adenylate cyclase activity to reduce excitation in the CNS (Brinton et al. 2008, Thomas 2008, Do Rego et al. 2009, King 2013). The single-transmembrane PGRs are progesterone receptor membrane component one (PGMRC1, also termed as 25-Dx in rat and Hpr6 in human) and the closely related PGMRC2, which displays moderately high binding affinity for PROG. It is also worth mentioning that the classical PGR can also mediate the effects of PROG on signaling pathways through rapid nongenomic extranuclear mechanisms (Singh et al. 2013).

Besides PROG itself, its metabolites also exert important effects in the nervous system through the involvement of multiple receptors and signaling pathways. Indeed, PROG is converted into dihydroprogesterone (DHP) by the enzyme $5 \alpha$-reductase. In turn, DHP is further converted into allopregnanolone or isopregnanolone by $3 \alpha$-hydroxysteroid oxidoreductase or $3 \beta$-hydroxysteroid oxidoreductase, respectively (Melcangi et al. 2008). These enzymatic conversions have a deep impact on the mechanism of action of PROG. Indeed, while DHP, like its precursor, is able to interact with the classical steroid receptor, the PGR (Melcangi et al. 2008), allopregnanolone is a potent ligand of a nonclassical steroid receptor, such as the gamma-aminobutyric acid type A (GABA-A) receptor (Lambert et al. 2003, Belelli \& Lambert 2005) (Fig. 1). Furthermore, several effects of allopregnanolone appear to be mediated by PAQR and by the pregnane xenobiotic receptor (PXR) (Cooke et al. 2013, Frye et al. 2013). In contrast, isopregnanolone does not bind directly to the GABA-A receptor (Bäckström et al. 2005, Bitran et al. 1991), but it antagonizes the effect of allopregnanolone on the GABA-A receptor (Wang et al. 2002). Many reviews have recently discussed the effects of PROG and its metabolites in the nervous system (Melcangi et al. 2014, 2015, Schumacher et al. 2014, 2016, Barros et al. 2015). On the contrary, little attention was addressed on the actions exerted by synthetic progestins on the nervous functions. In this study, data so far obtained will be reviewed.

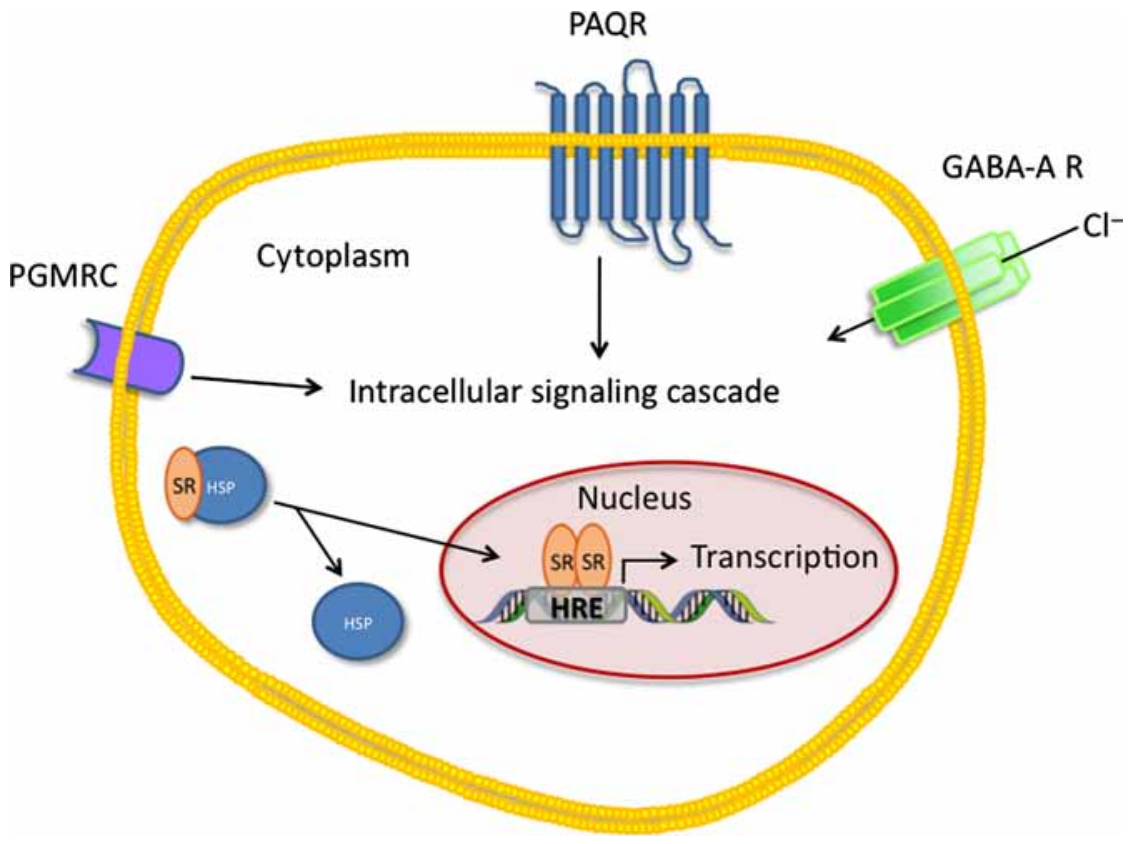

Figure 1

Schematic representation of the different mechanisms of action of progesterone, its metabolites, and progestins. As reported in the text, progesterone and progestins interact with the intracellular steroid receptor (SR), which is coupled to heat shock proteins (HSP) in the cytoplasm. After binding with its ligand, SR interacts into the nucleus as dimer with the hormone responsive elements (HRE), thus activating transcription of target genes. SR includes different kinds of receptors, such as progesterone receptor, androgen receptor, estrogen receptor, glucocorticoid receptor, and mineralocorticoid receptor. Moreover, progesterone, allopregnanolone, and progestins (see text for details) may interact with members of membrane receptor families, such as the seven-transmembrane progesterone adiponectin $\mathrm{Q}$ receptors (PAQR) and progesterone receptor membrane components (PGMRC), promoting intracellular signaling cascades. Furthermore, allopregnanolone interacts with GABA-A receptor, promoting a chloride $(\mathrm{Cl}-)$ influx.
๑) 2016 Society for Endocrinology Printed in Great Britain 


\section{Chemical structure and mechanism of action}

In recent years, several papers have tried to clarify the terminology used to describe synthetic steroids structurally distinct to PROG but designed to target the PGR. However, there is still confusion about which terminology should be used.

The term progestogens is a functional definition and refers to the broad class of progestational agents. These include both the natural hormone PROG and the synthetic progestational compounds. The latter are referred to as progestins (Stanczyk 2003).

Although progestogens are generally classified as compounds with progestational activity, meaning the capacity to induce secretory endometrium and support gestation, in the human only PROG is capable of maintaining pregnancy. Synthetic progestins commonly used in clinical practice, indeed, have been selected on other characteristics, like for instance greater bioavailability, half-life, and activity after oral administration or inhibition of ovulation (Pasqualini 1996, Sitruk-Ware 2000).

From the first progestin, synthesized by Hans $\mathrm{H}$. Inhoffen and Walter Hohlweg in 1938 (Inhoffen \& Hohlweg 1938), several synthetic progestins, which differ in their chemical structures and biological effect, have been synthesized.

These molecules are generally classified into two groups based on the structural similarities with testosterone or PROG.

\section{Progestins structurally related to testosterone}

Progestins structurally related to testosterone are subdivided into those containing an ethinyl group at carbon 17 and those nonethinylated (Fig. 2). The substitution of a hydrogen on C17 with an ethinyl group into the testosterone molecule increases the oral potency of these compounds (Sobey 2008). This led to the synthesis of the first oral progestin ethisterone. Subsequently, removal of the carbon-19 from ethisterone to form norethisterone changed the major hormonal effect from that of an androgen to that of a progestogen without destroying the oral activity. This characteristic is present in most of the progestins related to testosterone available now for therapeutic use (19-nortestosterone derivatives), conferring them progestational activity. Progestins belonging to the ethinylated group are further divided into those related to the parent steroid with 18 carbon (estrane), with a methyl group at carbon 13 and those with an ethyl group at carbon 13 (13-ethylgonanes, also known as gonanes) (Edgren \& Stanczyk 1999).

The nonethinylated group of progestins includes dienogest (DNG) and the spirolactone derivative drospirenone (DRSP), whose structure is similar to that of the aldosterone antagonist spironolactone. DRSP, compared with both estrane and 13-ethylgonanes, is the only exception in which the methyl group at carbon 10 has not been removed.

\section{Progestins structurally related to progesterone}

Progestins structurally related to PROG (Fig. 3) can be subdivided into 17-hydroxyprogesterone derivatives (or pregnanes 21 carbons) and 19-norpregnane derivatives (20 carbons) on the basis of whether or not they contain a methyl group on carbon 10, respectively (Stanczyk 2003). The deletion of the $\mathrm{CH}_{3}$ radical in position C19 of the hydroxyprogesterone skeleton confers to the 19-norpregnane derivatives higher progestational potency when compared with pregnane, making these molecules to bind more selectively to the PGR. In particular, nomegestrol acetate, 19-norprogesterone and promegestone (R5020) are the most selective agonists of the PGR, with little or no activity for other steroid receptors (Sitruk-Ware 2002, Schindler et al. 2003, GarcíaBecerra et al. 2004).

Pregnanes and 19-norpregnanes are further separated into classes of compounds with and without an acetyl group. Among the acetylated pregnane, the $17 \alpha$-hydroxyprogesterone derivative medroxyprogesterone acetate (MPA), is one of the best-known and most widely used progestins in the USA (Stanczyk \& Bhavnani 2014).

Finally, the retroprogesterone derivative dydrogesterone is a stereoisomer of natural PROG. Compared with other progestogens, whose molecular structure (with the four rings in a plane) is almost flat, retroprogesterone molecule is bent. This unique conformation is due to the presence of the methyl group at carbon 10 in $\alpha$-position, the hydrogen at C9 in $\beta$-position and an additional double bond between carbon 6 and 7 .

Unlike other progestogens, dydrogesterone is a highly selective progestin, binding almost exclusively PGR. This is due to the rigid conformation of its retrostructure, which is suitable for its interaction with PGR, but not with the other steroid hormone receptors (Colombo et al. 2006). In particular, dydrogesterone is inactive as agonists of human mineralocorticoid receptor (MR) and shows negligible androgenic, estrogenic or mineralocorticoid activities (Kuhl 2005, Rižner et al. 2011).

Published by Bioscientifica Ltd 

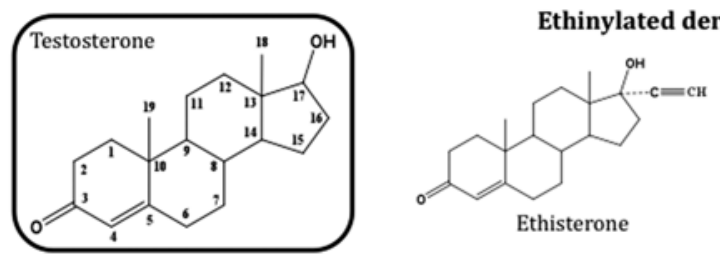

Ethisterone
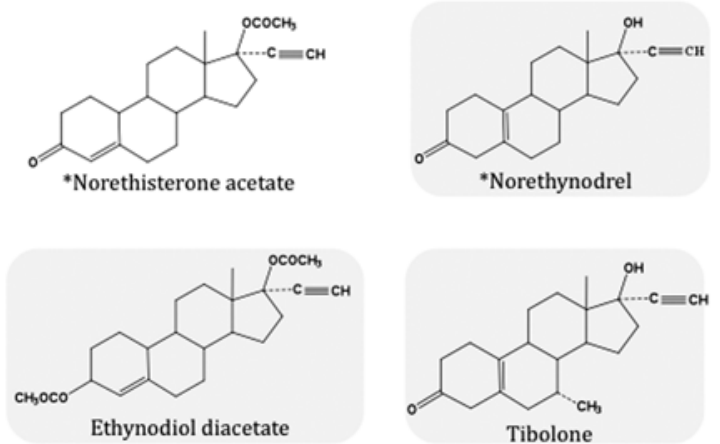
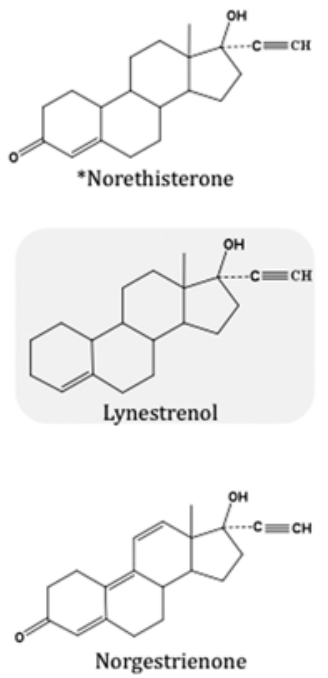

Ethinylated derivatives: 13-ethylgonanes
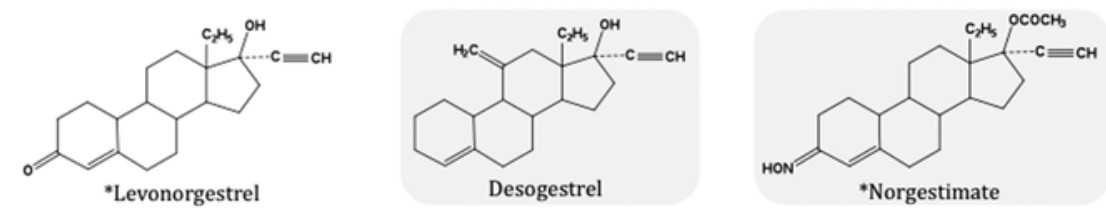

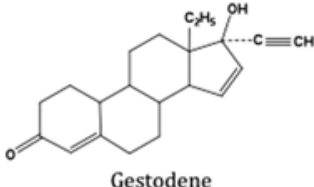

Gestodene

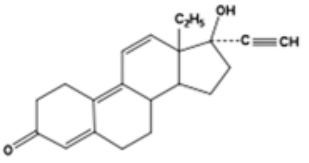

Gestrinone

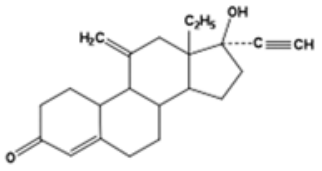

Etonogestrel

\section{Figure 2}

Chemical structure of progestins structurally related to testosterone. Surrounded by a solid line is the molecule of testosterone, surrounded by a dotted line is the spirolactone derivative drospirenone. In the gray panels are reported prodrugs. These latter molecules require in vivo biochemical transformation to active metabolites. Chemical structures of clinically relevant progestins are identified with an asterisk (*) before the name. Data from Liu et al. (2010) and Stuenkel et al. (2015).

\section{Interaction of progestins with steroid receptors}

Small structural changes of progestins may account for considerable differences in their pharmacological properties and actions. The chemical structure of progestins influences their binding affinity with receptors and, in turn, the transcriptional activity of the dimer complex. Thus, considering that progestins can be derivates of PROG, testosterone, and even spirolactone, it is not surprising that they can also bind with other members of the steroid receptor family, exhibiting additional nonprogestagenic biological effects.
Most progestins, indeed, also interact with the androgen receptor (AR), estrogen receptor (ER), glucocorticoid receptor (GR), and MR (Sitruk-Ware 2004). Progestins present clear differences in their binding affinities for AR, ER, GR, and MR based on the chemical structure of both the progestin and the ligandbinding domain of the steroid receptor. The interaction of progestins with one or more receptors, in turn, may be associated with an agonistic, antagonistic, or no effect according to the co-activators or co-repressors involved in the receptor interaction (Conneely \& Lydon 2000, Stanczyk et al. 2013).

Published by Bioscientifica Ltd. 

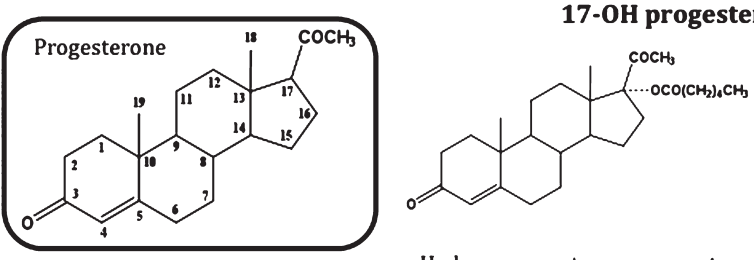

Hydroxyprogesterone caproate

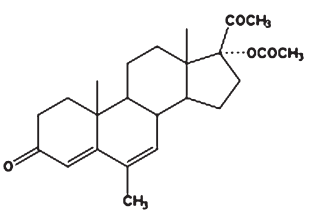

${ }^{*}$ Megestrol acetate

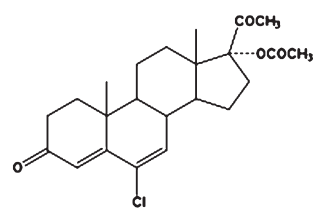

*Chlormadinone acetate

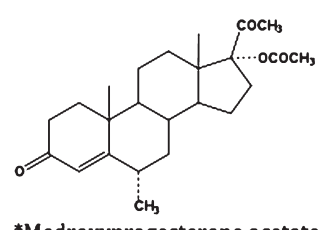

*Medroxyprogesterone acetate

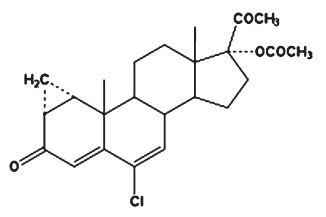

Cyproterone acetate

17-0H progesterone derivative: non acetilated<smiles>CCCC1=CC2C3CCC(C)(C(C)C)C3CCC2(C)C2CCC(=O)C=C12</smiles>

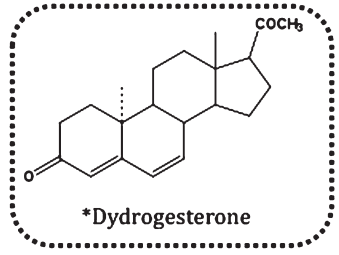

19-norpregnane derivatives acetilated

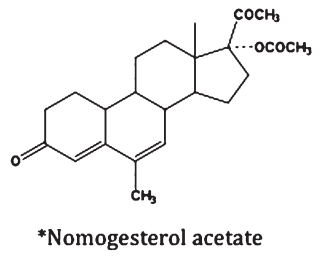

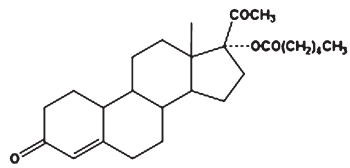

Gestonorone caproate<smiles>C[C@@H]1CC2C3CCC4=CC(=O)CCC4C3CCC2(C)[C@H]1O</smiles>

*Nestorone

19-norpregnane derivatives non acetilated

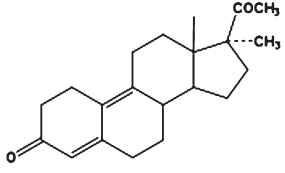

Demegestone

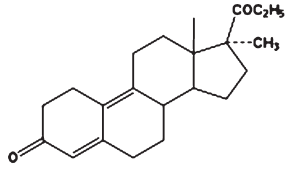

${ }^{*}$ Promegestone

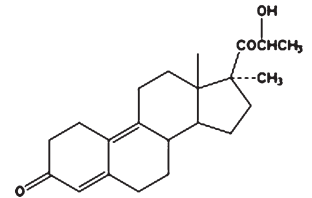

Trimegestone
Figure 3

Chemical structure of progestins structurally related to progesterone. Surrounded by a solid line is the molecule of progesterone, surrounded by a dotted line is the retroprogesterone dydrogesterone. Chemical structures of clinically relevant progestins are identified with an asterisk (*) before the name. Data from Liu et al. (2010) and Stuenkel et al. (2015).
Among 17-hydroxyprogesterone derivatives, cyproterone acetate (CPA), DNG, and chlormadinone acetate (CMA) are potent anti-androgenic compounds, whereas MPA transactivates both AR and GR (McLeod 1993, Bamberger et al. 1999, Raudrant \& Rabe 2003).

The 19-norpregnane derivatives like, for example, promegestone, trimegestone (TMG), nestorone, and nomogesterol acetate, are the most selective agonists of the PGR with very little or no activity for other steroid receptors (Sitruk-Ware \& Nath 2010, Stanczyk et al. 2013). On the other hand, it is quite common to find androgenic properties among progestins structurally related to testosterone like levonorgestrel (LNG), norethisterone (NET), and tibolone (TIB). Moreover, some reduced metabolites of progestins structurally related to testosterone, besides having some androgenic effects, also show a slight estrogenic activity (GarcíaBecerra et al. 2002). DRSP, since it is a derivative of the well-known MR antagonist spironolactone, has antimineralocorticoid properties (Oelkers et al. 1991, Delyani 2000, Oelkers 2004) and anti-androgenic effects (Muhn et al. 1995, Krattenmacher 2000). 
The finding that progestins can also interact with other steroid receptors (i.e., AR, ER, GR, MR) is indeed not surprising. All these proteins belong to the nuclear receptor superfamily and have structural similarity exhibiting a highly conserved overall domain structure (Germain et al. 2006, Pawlak et al. 2012). Progestins, which exhibit relatively high affinity to the AR, generally belong to the first-generation synthetic progestins (Stanczyk et al. 2013). Among these, there are MPA and norethynodrel, one of the first progestin synthesized (Sitruk-Ware 2000). NET (also known as norethindrone) and LNG are examples of progestins of second generation. They also have high binding affinity for the AR conferring them some undesirable androgenic effects (Nilsson \& von Schoultz 1989, Campos et al. 1999).

Over the more recent decades, newer progestins were synthesized with the goal of finding a molecule without any androgenic or glucocorticoid effect. These new progestins, beside having a strong progestational action, also exert anti-estrogenic, antigonadotropic, and antimineralocorticoid effects (Africander et al. 2011). Among these, there are the third-generation progestins (desogestrel or gestodene), derived from LNG group, developed to decrease androgenic activity (LeBlanc \& Laws 1999), and the fourth-generation progestins. In this latter group, nomegestrol acetate exhibits partial anti-androgenic activity (Lello 2010, Van Diepen et al. 2011) DNG, DRSP, and trimegestone have a significant anti-androgenic activity, whereas nestorone has no activity via the AR (Fotherby 1990, Philibert et al. 1999, Schindler et al. 2003).

In contrast to PROG, which also shows an affinity for membrane PGRs (Falkenstein et al. 1999, Zhu et al. 2003), very little is known concerning the possible binding of progestins to this receptor. As showed by Thomas et al. (2007), among the 30 steroidal compounds tested, only norprogesterone and pregna-4,9(11)-diene-3,20-dione displayed a relative binding affinity (RBA) of 51.8 and $50.9 \%$ compared with that of PROG, whereas the RBAs of the remaining progestins tested were less than $50 \%$ (Thomas et al. 2007).

However, no conclusive data about affinity of progestins for membrane PGRs are present in literature, so we cannot exclude that some of the effects of these synthetic compounds in the CNS could be mediated by these receptors.

It is worthwhile to note that, since the relative levels of different receptors can vary greatly in different tissues, the physiological effects of a particular progestin may be influenced by the different expression of steroid receptors in different cell types (Markov et al. 2010). The specific action of different progestins may also be influenced by other factors such as the bioavailable (free) fraction of both the circulating progestins and endogenous competing steroids. This, in turn, depends on the concentration and affinity of plasma binding proteins that bind steroids (i.e., albumin, corticosteroidbinding globulin (CBG), and sex hormone binding globulin (SHBG)) (Hammond 2002, Schindler et al. 2003) as well as by the metabolism of progestins, which can result in compounds that have different activities (Stanczyk 2003).

\section{Metabolism of progestins}

Most of progestins, like their related steroids (i.e., PROG and testosterone), contain a ketone group at carbon 3 and a double bond between carbons 4 and 5 $(\Delta 4$-3-ketone structure). These characteristics are the prerequisite for the progestogenic activity. Therefore, progestins can be metabolized by $5 \alpha$ - or $5 \beta$-steroid reductases and hydroxysteroid dehydrogenases in a similar manner as their parental compound. Apart from steroid $5 \alpha$-reductase isozyme family (e.g., SRD5A1, SRD5A2, and SRD5A3) (Azzouni et al. 2012), all the remaining enzymes involved in the two-step reduction process in humans belong to the aldo-keto reductase (AKR) superfamily. This includes steroid $5 \beta$-reductase or AKR1D1 (Di Costanzo et al. 2008, Chen et al. 2011) and AKR1C enzymes: AKR1C1 (20 $\alpha,(3 \alpha)$-hydroxysteroid dehydrogenase (HSD)) (Hara et al. 1996), AKR1C2 (type

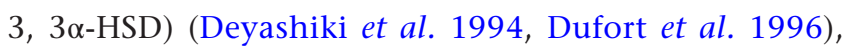
AKR1C3 (type 2, 3 $\alpha$-HSD and type 5, 17 $\beta$-HSD) (Khanna et al. 1995), and AKR1C4 (type 1, 3 $\alpha$-HSD) (Penning et al. 2000). These enzymes are promiscuous since they can catalyze 3-keto- and also 20-keto- and 17-keto-steroid reduction and are generally expressed in different tissues with the exception of AKR1C4, which is highly liver specific (Penning et al. 2000). The metabolism of progestins by the AKR1C enzymes may influence their availability for their cognate steroid hormone receptors and in turn their tissue-specific effects.

Reduction at a double bond between carbons 4 and 5 and at the carbonyl group at carbon 3, of NET, LNG, and gestodene, results in the formation of dihydro- and tetrahydro-derivatives (Stanczyk 2003). The $5 \alpha$-reduction of NET, even if confers a relatively high binding affinity to the AR, diminishes its androgenic potency (Lemus et al. 1997, García-Becerra et al. 2002, Moralí et al. 2002). The $3 \beta, 5 \alpha$-reduced metabolite of this compound is able to

Published by Bioscientifica Ltd 
activate gene transcription via ER, although its binding affinity is lower than estradiol (Larrea et al. 2001, Santillán et al. 2001, Pasapera et al. 2002, Enríquez et al. 2007). This finding is in accordance with further results, showing that tamoxifen (i.e., an estrogen binding site competitor) reduced the effect of $3 \beta, 5 \alpha-\mathrm{NET}$ administration, and that the activity of $5 \alpha$-NET is inhibited by the treatment with $\mathrm{CPA}$, a $3 \beta$-hydroxysteroid dehydrogenase $/ \Delta 4,5$ isomerase inhibitor (Larrea et al. 1987).

The 17-hydroxyprogesterone derivative CMA, together with MPA, is one of the first PROG derivatives. Like PROG, it has a $\Delta 4-3$-ketone structure. Reduction of the 3-keto group with preservation of the $\Delta 4$-double bond results in the formation of 3 $\alpha$-hydroxy-CMA, which exhibits strong anti-androgenic activity (Rabe et al. 2012). On the other hand, although MPA also possesses a $\Delta 4$-3-ketone structure, is not metabolized in the same way as the related steroid PROG, probably because of the steric hindrance due to the acetate group at carbon 17 (Stanczyk 2003). Indeed, MPA undergoes ring A reduction and hydroxylation at carbons 6 (Stanczyk et al. 2013).

The hydroxylation of the 19-norpregnane derivatives TMG into $1 \beta$ - and $6 \beta$-hydroxy-TMG metabolites confers progestogenic potency to these compounds.

The retroprogesterone derivative dydrogesterone, after its oral administration, is rapidly absorbed and metabolized into its active $20 \alpha$-dihydro metabolite $(20 \alpha-$ DHD) by hydrogenation of the 20-ketogroup (Beranič et al. 2011). Both human AKR1C isoforms, AKR1C1 and AKR1C2 can metabolize dydrogesterone with high efficacy, whereas AKR1C3 is less active (Beranič et al. 2011, 2012). Interestingly, although dydrogesterone is close in structure to progesterone, it is metabolized by AKR enzymes only to $20 \alpha$-DHD, whereas progesterone is transformed to several products including $5 \alpha$-pregnane, $5 \beta$-pregnane and 4-pregnene metabolites (Rižner \& Penning 2014). Recently, Olbrich et al. (2016) showed an involvement of cytochrome P450 isozymes in the metabolism of dydrogesterone.

Some of the progestins lack $\Delta 4$-3-ketone structure. Thus, they require in vivo biochemical transformation to active metabolites in order to exert progestational activity. Among these, norethynodrel, lynestrenol, and ethynodiol diacetate are prodrugs of NET. TIB is a derivative of norethynodrel, however, in contrast to its precursor, it is not converted to the progestin NET but it is transformed to other active metabolites. These metabolites are $\Delta 4$ isomer, such as $7 \alpha$-methyl-NET, as well as the $3 \alpha-$ and $3 \beta$-hydroxy metabolites. The former is generated by the enzyme $3 \beta$-hydroxysteroid dehydrogenase-isomerase, and exhibits a moderate androgenic and progestogenic activity. Conversion of TIB into $3 \alpha$ - or $3 \beta$-hydroxytibolone depends on the tissue where its metabolism occurs. In peripheral tissues, AKR1C1 and AKR1C2 form $3 \beta$-hydroxytibolone which exhibits estrogenic activity, whereas in liver, TIB is reduced to $3 \alpha$-hydroxytibolone by AKR1C4 which functions predominantly as $3 \alpha$-hydroxysteroid dehydrogenase (Steckelbroeck et al. 2004). This explains why $3 \alpha$-hydroxytibolone is the major circulating metabolite, whereas $3 \beta$-hydroxytibolone is the major metabolite in target tissues (Penning et al. 2014). Interestingly, AKR1C2 exhibits different stereochemical preference depending on the ketosteroid substrate. Indeed, it produces $3 \alpha$-products with the potent androgen $5 \alpha$-dihydrotestosterone ( $5 \alpha$-DHT) behaving as an efficient $3 \alpha$-hydroxysteroid dehydrogenase, whereas it inverts its stereospecificity with TIB acting as a $3 \beta$-hydroxysteroid dehydrogenase (Steckelbroeck et al. 2004, Rižner \& Penning 2014). Finally, TIB can also be metabolized, in less amount, to the potent estrogen $7 \alpha$-methylethinylestradiol (Wiegratz et al. 2002). The enzymatic pathway for this latter conversion, however, has not been clearly characterized (Bodine et al. 2002, Wiegratz et al. 2002, Dröge et al. 2007, Zacharia et al. 2007, Rabe et al. 2012). Norethynodrel which is identical to TIB except for lacking a methyl group at carbon 7, follows the same stereochemical outcome as observed for TIB suggesting that the reduction of the 3-ketosteroid by AKR1C isoforms is not influenced by the 7-methyl group (Jin et al. 2012).

Desogestrel and norgestimate (NGM) are also prodrugs converted in the progestationally active metabolites, such as etonogestrel (also called 3-ketodesogestrel) and LNG, respectively (Stanczyk et al. 2013).

It has been well established that PROG can exert multiple effects on neurons and glial cells by local metabolism to allopregnanolone (Singh 2007, Tsutsui 2008). This $3 \alpha, 5 \alpha$-reduced metabolite, due to a hydroxyl group at C3, does not interact with classical intracellular steroid receptors, but it is a potent positive modulator of GABA-A receptor and results in the potentiation of GABA-induced chloride conductance (Lambert et al. 2003, Belelli \& Lambert 2005). On the other hand, the conversion to $3 \beta, 5 \alpha-$ reduced metabolite (i.e., isopregnanolone), can antagonize the effects of allopregnanolone at GABA-A receptor (Bäckström et al. 2005, Bitran et al. 1991). As mentioned above, progestins are also converted in both $3 \alpha, 5 \alpha$ - and $3 \beta, 5 \alpha$-reduced metabolites, but the action exerted by these metabolites on GABA-A receptor needs to be clarified.

Published by Bioscientifica Ltd 


\section{Effect of progestins in the nervous system}

During lifetime, healthy women may assume progestin compounds in order to control ovary functions at younger ages, or to limit complications of menopause. Thus, the progestin compound assumed is related to the peripheral function that a woman wants to control. As previously described, a plethora of progestin molecules have been synthesized, with different characteristics. However, little information is available about their effects on brain functions. Here, we discuss some data concerning their neural effects in animal models and in women having combined oral contraceptive (COC) or hormone replacement therapy (HRT).

\section{Observations in animal models}

Ovariectomy is a surgical procedure widely used in experimental models to mimic the hormone drop occurring in menopause. Indeed, this technique has been used to explore the effects of different progestin compounds, alone or in combination with estrogens, on allopregnanolone and $\beta$-endorphin levels. As mentioned above, the PROG metabolite allopregnanolone interacts with GABA-A receptor, and the reduction of its levels in menopause are thought to negatively influence women's psychosocial behavior (Sator et al. 1999). Clinical evidence, indeed, suggested that the administration of PROG to peri-menopausal women promotes the length and quality of sleep (Gruber \& Huber 2003). Also alterations of the levels of $\beta$-endorphins (i.e., ligands of the opioid receptor exerting analgesic effects) have been reported in menopausal women, and their drop is significantly correlated to hot flushes (Tepper et al. 1987). Ovariectomy in Wistar rats reduces levels of $\beta$-endorphins and allopregnanolone in several brain regions, such as frontal and parietal lobes, hippocampus, hypothalamus, as well as in anterior pituitary and serum, whereas it increases allopregnanolone content in the adrenal gland (Genazzani et al. 2007). The progestin DRSP, when orally administered to ovariectomized rats, was able to increase the levels of $\beta$-endorphin (Genazzani et al. 2007), without affecting the reduced content of allopregnanolone. The concomitant administration of DRSP and estradiol valerate (E2-V) was able to increase $\beta$-endorphin and allopregnanolone levels. The same effect was also obtained by the administration of E2-V alone (Genazzani et al. 2007). Also CMA was able to increase allopregnanolone content in hippocampus, hypothalamus and anterior pituitary, but only if administered in combination with
E2-V (Pluchino et al. 2009). In contrast, dydrogesterone alone increased allopregnanolone levels in frontal lobe, hippocampus, hypothalamus, and serum. This treatment was ineffective on $\beta$-endorphin levels that were increased only when dydrogesterone was administered in combination with E2-V (Pluchino et al. 2008). Nestorone administration was able to increase $\beta$-endorphin levels in hippocampus, while, when administered in combination with E2-V, possessed a synergistic effect on allopregnanolone levels in hippocampus and anterior pituitary (Lenzi et al. 2009). Also treatment with nomegestrol acetate influences $\beta$-endorphin and allopregnanolone levels in ovariectomized rats. In particular, when this progestin was administered alone, it induced an increase of allopregnanolone levels in hippocampus. However, when nomegestrol acetate was administered with E2-V, it induced an increase of allopregnanolone levels in both the hypothalamus and anterior pituitary (Lenzi et al. 2008). This pattern of effects was a peculiarity of the nervous system. Indeed, administration of this progestin, alone or in combination with $\mathrm{E} 2-\mathrm{V}$, was able to reduce allopregnanolone levels in adrenal gland (Lenzi et al. 2008). Administration of high doses of nomegestrol acetate $(1 \mathrm{mg} / \mathrm{kg} /$ day $)$ also increased hippocampal and hypothalamic levels of $\beta$-endorphin, while only when combined with E2-V, $\beta$-endorphin levels were increased also in the anterior pituitary and plasma (Lenzi et al. 2008). Finally, also the first-generation molecule MPA was able to increase allopregnanolone levels in the frontal and parietal lobes, hypothalamus, hippocampus, and anterior pituitary and, when in combination with E2-V, to a greater degree respect to estrogen alone (Bernardi et al. 2006). The authors proposed that the increased levels of allopregnanolone may be a consequence of SRD5A and ARK1C modulation mediated by the combined treatment (Bernardi et al. 2006). On the other hand, the effect on $\beta$-endorphin levels could be supposed based on progestin structure. For example, MPA has a glucocorticoid activity that could inhibit the release of $\beta$-endorphins (Szot et al. 2004). In contrast, DRSP, through a combination of progestin, antimineralcorticoid, and anti-androgenic effects, is able to positively regulate $\beta$-endorphin levels (Genazzani et al. 2007).

Estrogens exert beneficial effects on the bioenergetics system of the brain, acting also on mitochondrial functions (Rettberg et al. 2014), which is important to sustain the energy demand of the nervous system for neurotransmission and plasticity. The drop in estrogens levels during menopause is thought to deeply affect

Published by Bioscientifica Ltd 
mitochondrial respiration and ATP generation. In agreement, OVX mice displayed decreased mitochondrial bioenergetics, a condition that could be reversed by estrogen treatment, when administered immediately after surgical procedure (Yao et al. 2012). Also PROG can modulate mitochondrial functions. Indeed, PROG and E2 are able to increase the respiratory activity of brain mitochondria in OVX rats. These effects are coupled to a reduced free radical leak and lipid peroxidation, suggesting that these compound could promote efficient and balanced bioenergetics (Irwin et al. 2008). Also other progestins may impact mitochondrial functions. In particular, as PROG, LNG, and nestorone significantly increased ATP synthase $\alpha$-subunit (complex V) expression, exerting also protective effects. In contrast, MPA did not exert similar effects. However, both MPA and LNG produced an increased $\mathrm{Bax} / \mathrm{Bcl}-2$ ratio, suggesting apoptosis (Liu et al. 2010). Overall, these data suggest that hormonal replacement may affect brain mitochondrial efficiency.

Also the effect of COC has been explored in animal models. For example, a study in female rats treated with a contraception pill containing ethinyl estradiol (EE) and norgestrel revealed that the progestin component of the pill produces a depletion of biogenic amines particularly in the hypothalamus and pons/medulla oblongata (Shetty \& Gaitonde 1980). COC administration (EE+LNG) to female rats produced a decline in learning and memory (Simone et al. 2015). In addition, the same combination reduced allopregnanolone, PROG, and pregnenolone levels in cerebral cortex, hippocampus, and plasma, resulting in an impairment in social behavior and sexual motivation (Follesa et al. 2002, Sassoè-Pognetto et al. 2007, Santoru et al. 2014). An impaired social behavior was also observed in monkeys (Macaca fascicularis), after 2 years of treatment with EE and LNG (Henderson \& Shively 2004). Moreover, long-term administration of this combination was also able to alter GABA-A receptor composition, increasing the expression of the $\gamma 2$-subunit and thus affecting anxiety behavior in female rats (Follesa et al. 2002). A recent study addressed the question which component of the pill would be responsible for such alterations. Thus, female rats were treated with a combination of EE and LNG, or with the single molecules. The results obtained suggest that either EE or LNG alone or their combination were able to decrease pregnenolone, PROG, and allopregnanolone in hippocampus and cerebral cortex. However, only the progestin affected the expression of the $\alpha 1$ GABA-A receptor subunit in cerebral cortex, whereas LNG, alone or in combination, altered the levels of the $\gamma 2$-subunit, increasing anxiety behavior in the elevated plus maze (Porcu et al. 2012). These results may suggest that changes in GABA-A receptor expression were not due to the reduced content of neuroactive steroids, but rather due to LNG component. Since androgens are able to affect GABA-A receptor composition (McIntyre et al. 2002, Henderson et al. 2006, Jones et al. 2006), a possible explanation of this effect could be ascribed to the androgenic activity of LNG.

\section{Environmental effects in aquatic life}

An emerging issue, concerning the role of these compounds on brain functions, is the effect of environmental relevant concentrations of PROG or progestins. Observations so far obtained underline the risk for the aquatic wildlife. For instance, decreased fecundity was observed in zebrafish (Danio rerio) after the exposition to MPA or dydrogesterone (Zhao et al. $2015 a$ ). Moreover, the effect of norgestrel exposure was evaluated in the hypothalamic-pituitary-gonadal (HPG) and hypothalamic-pituitary-adrenal (HPA) axes of juvenile zebrafish. An influence on sex differentiation was observed, with a shift in the sex ratio toward males or females depending on the dose. This shift was probably due to altered sex hormone levels, as a consequence of changes in the transcription of genes encoding enzymes of steroidogenesis (Liang et al. 2015a). Moreover, also the exposition to norgestrel in zebrafish eleuthero embryos produced alterations in many genes related to production of steroids (e.g., star, cyp19a1a, cyp11b) or their actions (Pgr and $A r$ ) (Liang et al. 2015b). This progestin, affecting the first step of the synthesis of thyroid hormones, seems also to exert an effect in the hypothalamic-pituitary-thyroid axis. Indeed, norgestrel induced the gene expression of the sodium/iodide symporter that is responsible for the intake of iodide anion into the follicular cells (Liang et al. 2015c). DRSP affects central functions in zebrafish brain, disturbing the circadian rhythm network (Zucchi et al. 2014, Zhao et al. 2015b). Environmental relevant doses of LNG (31 ng/L) affects the reproductive system of male pubertal roach (Rutilus rutilus), acting on the pituitary expression of gonadotrophins and on the sex steroid levels. Females were also affected by this progestin, even if at higher doses (Kroupova et al. 2014). LNG was able to disrupt the sexual development also in Xenopus laevis. In particular, the expression of follicle-stimulating hormone $\beta$-subunit was affected in a specific way in relation to the sex, LNG concentration, and stage of development, whereas the expression of luteinizing hormone $\beta$-subunit $(\operatorname{lh} \beta)$ was reduced in both sexes (Lorenz et al. 2011a).

Published by Bioscientifica Ltd. 
Moreover, LNG impaired thyroid activity during the metamorphosis of $X$. laevis, producing a developmental arrest (Lorenz et al. 2011b). NET (168 $\pm 7.5 \mathrm{ng} / \mathrm{L})$ was able to reduce, even if not significantly, the levels of $\operatorname{lh} \beta$, and significantly those of ER $\beta$ in brain of female fathead minnow (Pimephales promelas) (Petersen et al. 2015).

The reported observations highlight that progestins concentration found in water could affect brain functions. This consideration may suggest potential actions on humans, possibly exposed to these compounds via contaminated drinking water and seafood, with possible additional effects in women already assuming a progestin compound.

\section{Clinical observations}

As depicted above, progestins may alter brain function in experimental models. However, whether these effects may also occur in brain of women on HRT or assuming COC, need to be elucidated. In particular, it is difficult to establish the impact of pharmacological regiments in healthy women, owing to the different preparations, doses, routes of administration, as well as the different study designs.

Progestins as components of HRT The Women's Health Initiative (WHI) Memory Study reported a decline of cognitive functions in postmenopausal women treated with conjugated equine estrogen (CEE) and MPA (Shumaker et al. 2003). The same combination produced, in postmenopausal women independently of their age, a decline in verbal memory, which is considered a predictor of Alzheimer's disease (Marra et al. 2015). In contrast, estrogen treatment alone was beneficial, but only in younger postmenopausal women (Maki \& Sundermann, 2009). However, DNG, when combined with E2-V, was effective in improving the vigilance decrement, accounting for daytime fatigue. As detected by lowresolution brain electromagnetic tomography (LORETA), this combination, but not E2-V alone, increased activity in the right prefrontal, temporal, and superior parietal cortices and in the anterior cingulate gyrus (Saletu et al. 2005). In another study, insomniac postmenopausal women were tested with LORETA during a two-tone oddball paradigm (i.e., an auditory discrimination task). Data indicated that $\mathrm{E} 2-\mathrm{V}+\mathrm{DNG}$ combination was able to increase the stimulus-induced cortical arousal in the primary and higher-order auditory cortex; an effect that was not achieved by E2-V treatment alone
(Anderer et al. 2004). Moreover, the combination of EE and NET acetate produced, during a spatial working memory task, a higher activation of prefrontal cortex compared with placebo (Smith et al. 2006). Furthermore, a direct influence of estrogen and PROG on memory has been widely demonstrated (Schneider \& Farlow 1997, Choi et al. 2003, Bimonte-Nelson et al. 2004, Walf et al. 2006). However, the mechanisms involved in these processes have not been yet fully identified. In particular, contradictory results have been so far obtained about PROG. For example, while estrogen seems to exert a positive action on memory, PROG administration to women with Alzheimer's disease (Honjo et al. 2005) and in animal models (Bimonte-Nelson et al. 2006) seems to disrupt this effect. However, recent observations (Barros et al. 2015) suggest that the effect of PROG on memory is dependent on the time of administration (e.g., chronic exposure before learning vs acute administration after training). Moreover, as suggested by animal models, also the schedule of PROG treatment could be relevant. Indeed, continuous vs cyclic administration may produce different effects. For example, in hippocampus of OVX rats, no differences between vehicle-treated animals and rats administered with E2 and continuous PROG were observed. In contrast, in the same model, E2 and cyclic PROG treatment improved the expression of gene involved in mitochondrial energy, redox homeostasis, insulin signaling and cholesterol trafficking (Zhao et al. 2012). These results are also relevant in the context of HRT. Since the WHI study reported that combined estrogen-progestin regimens could increase the risk to develop dementia, the data here discussed may help the comprehension of the leading causes (Barros et al. 2015).

\section{Progestins as components of oral contraceptives In women assuming COC, the} situation seems to be more complicated. For instance, only marginal effects in the response inhibition have been observed in women who underwent EE and LNG combination (Gingnell et al. 2016). In addition, in healthy COC-naïve women, a low-dose combination was ineffective on mood (Rapkin et al. 2006). On the other hand, in another study enrolling women with previous history of COC-induced adverse mood, it was reported that the administration of EE and LNG produced depressed mood, mood swings, fatigue and lower emotional-induced reactivity in brain (i.e., in left insula, left middle frontal gyrus, and bilateral inferior frontal gyri) of COC users vs placebo controls
() 2016 Society for Endocrinology Printed in Great Britain
Published by Bioscientifica Ltd 
(Gingnell et al. 2013). Moreover, healthy women, with no previous history of depression, reported increased anxiety and mood disorders after a long-acting subdermal implant of LNG (Wagner \& Berenson 1994). Furthermore, different combinations of COC decreased plasma levels of allopregnanolone (Follesa et al. 2002, Paoletti et al. 2004, Rapkin et al. 2006). On the contrary, DRSP or chlormadinone were able to reduce anxiety and mood swings (Paoletti et al. 2004, Huber et al. 2008). Possible differences in cognitive performances have also been evaluated between COC users and nonusers. In particular, a better performance in verbal memory task has been identified in COC users vs nonusers (Gogos 2013), while other observations reported no changes (Islam et al. 2008, Mihalik et al. 2009). COC users outperform in associative learning (Beck et al. 2008, Holloway et al. 2011), and better results were obtained also in verbal fluency and mental rotation (Wharton et al. 2008, Griksiene \& Ruksenas 2011) when compared with nonusers. On the contrary, other observations reported no differences in spatial ability, verbal fluency, and attention (Rosenberg \& Park 2002, Islam et al. 2008, Mordecai et al. 2008, Nielsen et al. 2011, Gogos 2013).

As recently emerged, discordant results on the effects of COC in human brain have also been obtained by imaging studies (Gogos et al. 2014, Pletzer \& Kerschbaum 2014, Toffoletto et al. 2014). A possible explanation may be due to the molecular structure and specific generation of progestin component into $\mathrm{COC}$, an issue that received little attention in the studies performed so far (Toffoletto et al. 2014). For instance, the 'androgenicity' of progestin compound into the pill may affect brain anatomy and consequent cognitive skills. Indeed, Pletzer et al. (2015) recently reported that frontal gray matter volume and face recognition performance are differentially affected in COC users depending on the androgenic vs nonandrogenic potency of the progestin compound. An increased volume in the parahippocampal and fusiform gyri and in cerebellum of women assuming a nonandrogenic progestin was also reported. This was accompanied by a better performance in the face recognition test with respect to the COC users with an androgenic progestin component in the pill and non-COC users (Pletzer et al. 2015).

\section{Protective effects of progestins in the brain}

Recently, it has been proposed that some of the protective effects exerted by PROG in models of neurodegeneration and trauma (Melcangi \& Garcia-Segura 2010, Giatti et al. 2015, Melcangi et al. 2015) could also be achieved through the administration of a progestin compound, such as nestorone. In particular, this progestin (i.e., a potent PGR agonist) was studied in different experimental models to test possible neuroprotective effects. In the wobbler mutant mice, a model for progressive motoneuron degeneration, nestorone administration restored the spinal cord abnormalities and inverted the curved digits in forelimbs, typical of the pathology. Moreover, it increased cholineacetyltransferase, glutamine synthase, and nuclear factor of kappa light polypeptide gene enhancer in B-cells (NF-kB) inhibitor expression, while decreased astrogliosis and the expression of microglial marker lymphocyte function-associated antigen 1 , TNF- $\alpha$, inducible nitric oxide synthase, and NF-кB (Meyer et al. 2015). Neuroprotective and anti-inflammatory effects were also obtained in three different models of multiple sclerosis, such as the EAE mice, the cuprizone feeding, and the lysolecitin-induced demyelination models. In particular, in EAE mice, nestorone was able to decrease the neurological disability and increased the motor behavior in affected animals. In this experimental model, this progestin also decreased microglial reactivity in hippocampus, and it was able to promote cell proliferation and double-immunocortinpositive neuroblast in the same brain region, increasing also GABAergic interneurons (Garay et al. 2014). Female mice fed with cuprizone and injected with PROG or nestorone presented, to nearly the same extent, less astrocyte and microglial activation. An increased expression of two important myelin proteins (i.e., myelin basic protein and proteolipid protein), and increased density of both precursor and mature oligodendrocytes was also observed in this experimental model (El-Etr et al. 2015). Finally, the myelin-promoting effects of nestorone were evaluated in organotypic cultures of cerebellar slices from postnatal rodents, treated with lysolecitin. The synthetic progestin was able to promote the remyelination of neurons by oligodendrocytes, through a mechanism involving recruitment and maturation of oligodendrocytes precursor cells. The effects exerted by nestorone are probably due to its interaction with the intracellular PGR, because these effects were not observed in slices from PGR knockout animals (Hussain et al. 2011).

Also in a model of ischemia (i.e., the middle cerebral artery occlusion mice), nestorone exerted neuroprotective effects similar to PROG, reducing the total infarct volume and increasing the time spent by lesioned mice on the rotarod, compared with vehicle animals (Liu et al. 2012).

In contrast to what is observed with nestorone, MPA, one of the most prescribed progestin compound in HRT regiment, does not exert protective effects.

Published by Bioscientifica Ltd 
WHI results reported an increased risk for breast cancer, coronary heart disease, stroke, and pulmonary embolism in the CEE + MPA arm of the study (Rossouw et al. 2002). In addition, many studies report conflicting results of PROG vs MPA administration in different animal models and HRT patients (Singh \& Su 2013, Stanczyk \& Bhavnani 2015). Observations so far obtained suggest that, even if PROG and MPA are nearly identical in preventing the uterotrophic effects of unopposed estrogen treatment, they are profoundly different in their mechanism of action on brain. Indeed, both steroids can bind to PGR, but MPA, unlike PROG, is also able to bind AR and GR (Schindler et al. 2003) with a 300-fold higher affinity (Koubovec et al. 2005). In experimental neurodegenerative models, PROG, but not MPA, exerts protective effects. For instance, in cerebral cortical explants, PROG increased expression and protein levels of the brain-derived neutrophic factor, while MPA exerted an inhibitory effect (Jodhka et al. 2009). In hippocampal cultures, PROG was protective by reducing the $\mathrm{Ca}^{2+}$ influx mediated by glutamate, through the activation of extracellular signal-regulated kinase signaling and the promotion of the transcription of anti-apoptotic factors, such as B-cell lymphoma 2 (BCL2). In contrast, MPA was ineffective in contrasting the $\mathrm{Ca}^{2+}$ influx, did not promote the transcription of BCL2 and inhibited the protective action of estradiol, when co-administered (Nilsen \& Brinton 2002, 2003). Similarly, when tested for glycolysis, oxidative stress, and mitochondrial function in brain, OVX rats treated with MPA showed a decline in glycolytic and oxidative phosphorylation protein and activity, suggesting mitochondrial impairment (Irwin et al. 2011). Many neuroprotective effects of PROG seem to be mediated by its conversion into neuroactive metabolites, such as DHP and allopregnanolone (Melcangi et al. 2014, Giatti et al. 2015). Interestingly, it has been reported that MPA could antagonize the conversion of PROG into allopregnanolone, through the inhibition of ARK1C ezyme (Khanim et al. 2014), possibly blocking progesterone neuroprotective effects (Stanczyk \& Bhavnani 2015).

\section{Conclusions}

Since the synthesis of the first progestin in 1938, the increasing interest and request for efficient compounds stimulated the production of new molecules, possibly with high affinity for PGR. However, despite the large clinical use of these molecules, their possible effects on brain functions have been little explored. In recent years, preclinical and clinical studies tried to fill this gap of knowledge, even though very different study designs and few attention of the molecules assumed may have produced confounding results, in particular in human studies. Moreover, all the combinations in terms of dose, duration of exposure, and route of administration, baseline hormonal status, and age of treated women, just to cite some, increased the complexity of this field. Furthermore, another level of complication, highly ignored, is represented by their mechanism of action, such as the interaction with different receptors as well as by their metabolism. In particular, this latter aspect should be further explored because the effects of PROG in brain are deeply linked to its metabolism, and, possibly, also progestin compounds are exposed to the same fate. For these reasons, rigorous guidelines should be proposed, and new animal and human studies performed, in order to dissect this intriguing and fascinating field of research.

Declaration of interest

The authors declare that there is no conflict of interest that could be perceived as prejudicing the impartiality of this review.

\section{Funding}

The authors acknowledge financial support from the Fondazione Cariplo to R C M (grant number 2012-0547).

\section{References}

Africander D, Verhoog N \& Hapgood JP 2011 Molecular mechanisms of steroid receptor-mediated actions by synthetic progestins used in HRT and contraception. Steroids 76 636-652. (doi:10.1016/ j.steroids.2011.03.001)

Anderer P, Saletu B, Saletu-Zyhlarz G, Gruber D, Metka M, Huber J \& Pascual-Marqui RD 2004 Brain regions activated during an auditory discrimination task in insomniac postmenopausal patients before and after hormone replacement therapy: low-resolution brain electromagnetic tomography applied to event-related potentials. Neuropsychobiology 49 134-153. (doi:10.1159/000076722)

Azzouni F, Godoy A, Li Y \& Mohler J 2012 The 5 alpha-reductase isozyme family: a review of basic biology and their role in human diseases. Advances in Urology 2012 530121. (doi:10.1155/2012/530121)

Bäckström T, Wahlström G, Wahlström K, Zhu D \& Wang MD 2005 Isoallopregnanolone an antagonist to the anaesthetic effect of allopregnanolone in male rats. European Journal of Pharmacology 512 15-21. (doi:10.1016/j.ejphar.2005.01.049)

Bamberger CM, Else T, Bamberger AM, Beil FU \& Schulte HM 1999 Dissociative glucocorticoid activity of medroxyprogesterone acetate in normal human lymphocytes. Journal of Clinical Endocrinology and Metabolism 84 4055-4061. (doi:10.1210/jcem.84.11.6091)

Banks JA \& Freeman ME 1980 Inhibition of the daily LH release mechanism by progesterone acting at the hypothalamus. Biology of Reproduction 22 217-222. (doi:10.1095/biolreprod22.2.217)

Barbaccia ML, Serra M, Purdy RH \& Biggio G 2001 Stress and neuroactive steroids. International Review of Neurobiology 46 243-272. (doi:10.1016/S0074-7742(01)46065-X) 
Barraclough CA, Camp P, Weiland N \& Akabori A 1986 Stimulatory versus inhibitory effects of progesterone on estrogen-induced phasic LH and prolactin secretion correlated with estrogen nuclear and progestin cytosol receptor concentrations in brain and pituitary gland. Neuroendocrinology 42 6-14. (doi:10.1159/000124241)

Barros LA, Tufik S \& Andersen ML 2015 The role of progesterone in memory: an overview of three decades. Neuroscience and Biobehavioral Reviews 49 193-204. (doi:10.1016/j.neubiorev.2014.11.015)

Baulieu EE, Schumacher M, Koenig H, Jung-Testas I \& Akwa Y 1996 Progesterone as a neurosteroid: actions within the nervous system. Cellular and Molecular Neurobiology 16 143-154. (doi:10.1007/ BF02088173)

Beck KD, McLaughlin J, Bergen MT, Cominski TP, Moldow RL \& Servatius RJ 2008 Facilitated acquisition of the classically conditioned eyeblink response in women taking oral contraceptives. Behavioural Pharmacology 19 821-828. (doi:10.1097/FBP.0b013e32831c3b82)

Belelli D \& Lambert JJ 2005 Neurosteroids: endogenous regulators of the GABA(A) receptor. Nature Reviews. Neuroscience 6 565-575. (doi:10.1038/nrn1703)

Beranič N, Gobec S \& Rižner TL 2011 Progestins as inhibitors of the human 20-ketosteroid reductases, AKR1C1 and AKR1C3. ChemicoBiological Interactions 191 227-233. (doi:10.1016/j.cbi.2010.12.012)

Beranič N, Brožič P, Brus B, Sosič I, Gobec S \& Rižner TL 2012 Expression of human aldo-keto reductase 1C2 in cell lines of peritoneal endometriosis: potential implications in metabolism of progesterone and dydrogesterone and inhibition by progestins. Journal of Steroid Biochemistry and Molecular Biology 130 16-25. (doi:10.1016/j. jsbmb.2011.12.011)

Bernardi F, Pluchino N, Pieri M, Begliuomini S, Lenzi E, Puccetti S, Casarosa E, Luisi M \& Genazzani AR 2006 Progesterone and medroxyprogesterone acetate effects on central and peripheral allopregnanolone and beta-endorphin levels. Neuroendocrinology $\mathbf{8 3}$ 348-359. (doi:10.1159/000095400)

Bimonte-Nelson HA, Singleton RS, Williams BJ \& Granholm A-CE 2004 Ovarian hormones and cognition in the aged female rat: II. progesterone supplementation reverses the cognitive enhancing effects of ovariectomy. Behavioral Neuroscience 118 707-714. (doi:10.1037/0735-7044.118.4.707)

Bimonte-Nelson HA, Francis KR, Umphlet CD \& Granholm A-C 2006 Progesterone reverses the spatial memory enhancements initiated by tonic and cyclic oestrogen therapy in middle-aged ovariectomized female rats. European Journal of Neuroscience 24 229-242. (doi:10.1111/j.1460-9568.2006.04867.x)

Bitran D, Hilvers RJ \& Kellogg CK 1991 Anxiolytic effects of 3 alphahydroxy-5 alpha[beta]-pregnan-20-one: endogenous metabolites of progesterone that are active at the GABAA receptor. Brain Research 561 157-161. (doi:10.1016/0006-8993(91)90761-J)

Bodine PVN, Harris HA, Lyttle CR \& Komm BS 2002 Estrogenic effects of $7 \alpha$-methyl-17 $\alpha$-ethynylestradiol: a newly discovered tibolone metabolite. Steroids 67 681-686. (doi:10.1016/S0039-128X(02)00021-1)

Brinton RD, Thompson RF, Foy MR, Baudry M, Wang J, Finch CE, Morgan TE, Pike CJ, Mack WJ, Stanczyk FZ, et al. 2008 Progesterone receptors: form and function in brain. Frontiers in Neuroendocrinology 29 313-339. (doi:10.1016/j.yfrne.2008.02.001)

Campos MG, Oropeza MV, Lemus AE, Garcia GA, Reynoso ME, Campos P \& Ponce-Monter H 1999 The androgenic effect of norethisterone and 5alpha-norethisterone on the contractile response of the rat vas deferens to methoxamine and serotonin. Life Sciences 64 PL227-PL233. (doi:10.1016/S0024-3205(99)00132-0)

Chan JR, Rodriguez-Waitkus PM, Ng BK, Liang P \& Glaser M 2000 Progesterone synthesized by Schwann cells during myelin formation regulates neuronal gene expression. Molecular Biology of the Cell $\mathbf{1 1}$ 2283-2295. (doi:10.1091/mbc.11.7.2283)

Chen M, Drury JE \& Penning TM 2011 Substrate specificity and inhibitor analyses of human steroid 503B2-reductase (AKR1D1). Steroids 76 484-490. (doi:10.1016/j.steroids.2011.01.003)
Choi JM, Romeo RD, Brake WG, Bethea CL, Rosenwaks Z \& McEwen BS 2003 Estradiol increases pre- and post-synaptic proteins in the CA1 region of the hippocampus in female rhesus macaques (Macaca mulatta). Endocrinology 144 4734-4738. (doi:10.1210/en.2003-0216)

Colombo D, Ferraboschi P, Prestileo P \& Toma L 2006 A comparative molecular modeling study of dydrogesterone with other progestational agents through theoretical calculations and nuclear magnetic resonance spectroscopy. Journal of Steroid Biochemistry and Molecular Biology 98 56-62. (doi:10.1016/j.jsbmb.2005.07.009)

Conneely OM \& Lydon JP 2000 Progesterone receptors in reproduction: functional impact of the A and B isoforms. Steroids 65 571-577. (doi:10.1016/S0039-128X(00)00115-X)

Cooke PS, Nanjappa MK, Yang Z \& Wang KKW 2013 Therapeutic effects of progesterone and its metabolites in traumatic brain injury may involve non-classical signaling mechanisms. Frontiers in Neuroscience 7 108. (doi:10.3389/fnins.2013.00108)

Delyani JA 2000 Mineralocorticoid receptor antagonists: the evolution of utility and pharmacology. Kidney International 57 1408-1411. (doi:10.1046/j.1523-1755.2000.00983.x)

Deyashiki Y, Ogasawara A, Nakayama T, Nakanishi M, Miyabe Y, Sato K \& Hara A 1994 Molecular cloning of two human liver 3 alphahydroxysteroid/dihydrodiol dehydrogenase isoenzymes that are identical with chlordecone reductase and bile-acid binder. Biochemical Journal 299 545-552. (doi:10.1042/bj2990545)

Di Costanzo L, Drury JE, Penning TM \& Christianson DW 2008 Crystal structure of human liver Delta4-3-ketosteroid 5beta-reductase (AKR1D1) and implications for substrate binding and catalysis. Journal of Biological Chemistry 283 16830-16839. (doi:10.1074/ jbc.M801778200)

Do Rego JL, Seong JY, Burel D, Leprince J, Luu-The V, Tsutsui K, Tonon M-C, Pelletier G \& Vaudry H 2009 Neurosteroid biosynthesis: enzymatic pathways and neuroendocrine regulation by neurotransmitters and neuropeptides. Frontiers in Neuroendocrinology 30 259-301. (doi:10.1016/j.yfrne.2009.05.006)

Dröge MJ, Oostebring F, Oosting E, Verheul HAM \& Kloosterboer HJ 2007 7alpha-Methyl-ethinyl estradiol is not a metabolite of tibolone but a chemical stress artifact. Menopause 14 474-480. (doi:10.1097/01.gme.0000247015.63877.d4)

Dufort I, Soucy P, Labrie F \& Luu-The V 1996 Molecular cloning of human type 33 alpha-hydroxysteroid dehydrogenase that differs from 20 alpha-hydroxysteroid dehydrogenase by seven amino acids. Biochemical and Biophysical Research Communications 228 474-479. (doi:10.1006/bbrc.1996.1684)

Edgren RA \& Stanczyk FZ 1999 Nomenclature of the gonane progestins. Contraception 60 313. (doi:10.1016/S0010-7824(99)00101-8)

El-Etr M, Rame M, Boucher C, Ghoumari AM, Kumar N, Liere P, Pianos A, Schumacher M \& Sitruk-Ware R 2015 Progesterone and nestorone promote myelin regeneration in chronic demyelinating lesions of corpus callosum and cerebral cortex. Glia 63 104-117. (doi:10.1002/glia.22736)

Enríquez J, Lemus AE, Chimal-Monroy J, Arzate H, García GA, Herrero B, Larrea F \& Pérez-Palacios G 2007 The effects of synthetic 19-noprogestins on osteoblastic cell function are mediated by their non-phenolic reduced metabolites. Journal of Endocrinology 193 493-504. (doi:10.1677/JOE-06-0038)

Falkenstein E, Heck M, Gerdes D, Grube D, Christ M, Weigel M, Buddhikot M, Meizel S \& Wehling M 1999 Specific progesterone binding to a membrane protein and related nongenomic effects on Ca2+-fluxes in sperm. Endocrinology 140 5999-6002. (doi:10.1210/ endo.140.12.7304)

Follesa P, Porcu P, Sogliano C, Cinus M, Biggio F, Mancuso L, Mostallino MC, Paoletti AM, Purdy RH, Biggio G, et al. 2002 Changes in GABAA receptor gamma 2 subunit gene expression induced by long-term administration of oral contraceptives in rats. Neuropharmacology 42 325-336. (doi:10.1016/S00283908(01)00187-3) 
Fotherby K 1990 Interactions with oral contraceptives. American Journal of Obstetrics and Gynecology 163 2153-2159. (doi:10.1016/ 0002-9378(90)90556-M)

Foy MR, Akopian G \& Thompson RF 2008 Progesterone regulation of synaptic transmission and plasticity in rodent hippocampus. Learning \& Memory 15 820-822. (doi:10.1101/lm.1124708)

Frye CA, Koonce CJ \& Walf AA 2013 Pregnane xenobiotic receptors and membrane progestin receptors: role in neurosteroid-mediated motivated behaviours. Journal of Neuroendocrinology 25 1002-1011. (doi:10.1111/jne.12105)

Garay L, Gonzalez Deniselle MC, Sitruk-Ware R, Guennoun R, Schumacher M \& De Nicola AF 2014 Efficacy of the selective progesterone receptor agonist Nestorone for chronic experimental autoimmune encephalomyelitis. Journal of Neuroimmunology 276 89-97. (doi:10.1016/j.jneuroim.2014.08.619)

García-Becerra R, Borja-Cacho E, Cooney AJ, Jackson KJ, Lemus AE, Pérez-Palacios G \& Larrea F 2002 The intrinsic transcriptional estrogenic activity of a non-phenolic derivative of levonorgestrel is mediated via the estrogen receptor-03B1. Journal of Steroid Biochemistry and Molecular Biology 82 333-341. (doi:10.1016/ S0960-0760(02)00192-9)

García-Becerra R, Cooney AJ, Borja-Cacho E, Lemus AE, Pérez-Palacios G \& Larrea F 2004 Comparative evaluation of androgen and progesterone receptor transcription selectivity indices of 19-nortestosterone-derived progestins. Journal of Steroid Biochemistry and Molecular Biology 91 21-27. (doi:10.1016/j.jsbmb.2004.02.003)

García-Segura LM, Chowen JA, P00E1rducz A \& Naftolin F 1994 Gonadal hormones as promoters of structural synaptic plasticity: cellular mechanisms. Progress in Neurobiology 44 279-307. (doi:10.1016/0301-0082(94)90042-6)

Genazzani AR, Pluchino N, Begliuomini S, Pieri M, Centofanti M, Freschi L, Casarosa E \& Luisi M 2007 Drospirenone increases central and peripheral beta-endorphin in ovariectomized female rats. Menopause 14 63-73. (doi:10.1097/01.gme.0000230348.05745.7d)

Germain P, Staels B, Dacquet C, Spedding M \& Laudet V 2006 Overview of nomenclature of nuclear receptors. Pharmacological Reviews $\mathbf{5 8}$ 685-704. (doi:10.1124/pr.58.4.2)

Ghoumari AM, Baulieu EE \& Schumacher M 2005 Progesterone increases oligodendroglial cell proliferation in rat cerebellar slice cultures. Neuroscience 135 47-58. (doi:10.1016/j.neuroscience.2005.05.023)

Giachino C, Galbiati M, Fasolo A, Peretto P \& Melcangi R 2003 Neurogenesis in the subependymal layer of the adult rat: a role for neuroactive derivatives of progesterone. Annals of the New York Academy of Sciences 1007 335-339. (doi:10.1196/annals.1286.032)

Giachino C, Galbiati M, Fasolo A, Peretto P \& Melcangi RC 2004 Effects of progesterone derivatives, dihydroprogesterone and tetrahydroprogesterone, on the subependymal layer of the adult rat. Journal of Neurobiology 58 493-502. (doi:10.1002/neu.10290)

Giatti S, Garcia-Segura LM \& Melcangi RC 2015 New steps forward in the neuroactive steroid field. Journal of Steroid Biochemistry and Molecular Biology 153 127-134. (doi:10.1016/j.jsbmb.2015.03.002)

Gingnell M, Engman J, Frick A, Moby L, Wikström J, Fredrikson M \& Sundström-Poromaa I 2013 Oral contraceptive use changes brain activity and mood in women with previous negative affect on the pill--a double-blinded, placebo-controlled randomized trial of a levonorgestrel-containing combined oral contraceptive. Psychoneuroendocrinology 38 1133-1144. (doi:10.1016/ j.psyneuen.2012.11.006)

Gingnell M, Bannbers E, Engman J, Frick A, Moby L, Wikström J \& Sundström-Poromaa I 2016 The effect of combined hormonal contraceptives use on brain reactivity during response inhibition. European Journal of Contraception \& Reproductive Health Care $\mathbf{2 1}$ 150-157. (doi:10.3109/13625187.2015.1077381)

Gogos A 2013 Natural and synthetic sex hormones: effects on higher-order cognitive function and prepulse inhibition. Biological Psychology 93 17-23. (doi:10.1016/j.biopsycho.2013.02.001)
Gogos A, Wu YC, Williams AS \& Byrne LK 2014 The effects of ethinylestradiol and progestins (2018the pill2019) on cognitive function in pre-menopausal women. Neurochemical Research 39 2288-2300. (doi:10.1007/s11064-014-1444-6)

Griksiene R \& Ruksenas O 2011 Effects of hormonal contraceptives on mental rotation and verbal fluency. Psychoneuroendocrinology 36 1239-1248. (doi:10.1016/j.psyneuen.2011.03.001)

Gruber CJ \& Huber JC 2003 Differential effects of progestins on the brain. Maturitas 46 S71-S75. (doi:10.1016/j.maturitas.2003.09.021)

Guerra-Araiza C, Amorim MAR, Camacho-Arroyo I \& Garcia-Segura LM 2007 Effects of progesterone and its reduced metabolites, dihydroprogesterone and tetrahydroprogesterone, on the expression and phosphorylation of glycogen synthase kinase- 3 and the microtubule-associated protein tau in the rat cerebellum. Developmental Neurobiology 67 510-520. (doi:10.1002/dneu.20383)

Hammond GL 2002 Access of reproductive steroids to target tissues. Obstetrics and Gynecology Clinics of North America 29 411-423. (doi:10.1016/S0889-8545(02)00008-6)

Hara A, Matsuura K, Tamada Y, Sato K, Miyabe Y, Deyashiki Y \& Ishida N 1996 Relationship of human liver dihydrodiol dehydrogenases to hepatic bile-acid-binding protein and an oxidoreductase of human colon cells. Biochemical Journal $\mathbf{3 1 3}$ 373-376. (doi:10.1042/bj3130373)

Henderson JA \& Shively CA 2004 Triphasic oral contraceptive treatment alters the behavior and neurobiology of female cynomolgus monkeys. Psychoneuroendocrinology 29 21-34. (doi:10.1016/ S0306-4530(02)00132-4)

Henderson LP, Penatti CAA, Jones BL, Yang P \& Clark AS 2006 Anabolic androgenic steroids and forebrain GABAergic transmission. Neuroscience 138 793-799. (doi:10.1016/j.neuroscience.2005.08.039)

Holloway JL, Beck KD \& Servatius RJ 2011 Facilitated acquisition of the classically conditioned eyeblink response in females is augmented in those taking oral contraceptives. Behavioural Brain Research 216 301-307. (doi:10.1016/j.bbr.2010.08.008)

Honjo H, Iwasa K, Kawata M, Fushiki S, Hosoda T, Tatsumi H, Oida N, Mihara M, Hirasugi Y, Yamamoto H, et al. 2005 Progestins and estrogens and Alzheimer2019s disease. Journal of Steroid Biochemistry and Molecular Biology 93 305-308. (doi:10.1016/j.jsbmb.2004.12.001)

Hossain MB, Oshima T, Hirose S, Wang J \& Tokumoto T 2015 Expression and purification of human membrane progestin receptor 03B1 (mPR03B1). PLOS ONE 10 1-16. (doi:10.1371/journal.pone.0138739)

Huber JC, Heskamp M-LS \& Schramm GAK 2008 Effect of an oral contraceptive with chlormadinone acetate on depressive mood202F: analysis of data from four observational studies. Clinical Drug Investigation 28 783-791. (doi:10.2165/0044011-200828120-00006)

Hussain R, El-Etr M, Gaci O, Rakotomamonjy J, Macklin WB, Kumar N, Sitruk-Ware R, Schumacher M \& Ghoumari AM 2011 Progesterone and Nestorone facilitate axon remyelination: a role for progesterone receptors. Endocrinology 152 3820-3831. (doi:10.1210/en.2011-1219)

Inhoffen HH \& Hohlweg W 1938 Neue per os-wirksame weibliche Keimdr00FCsenhormon-Derivate: 17-Aethinyl-oestradiol und Pregnen-in-on-3-ol-17. Die Naturwissenschaften 26 96. (doi:10.1007/ BF01681040)

Irwin RW, Yao J, Hamilton RT, Cadenas E, Brinton RD \& Nilsen J 2008 Progesterone and estrogen regulate oxidative metabolism in brain mitochondria. Endocrinology 149 3167-3175. (doi:10.1210/ en.2007-1227)

Irwin RW, Yao J, Ahmed SS, Hamilton RT, Cadenas E \& Brinton RD 2011 Medroxyprogesterone acetate antagonizes estrogen up-regulation of brain mitochondrial function. Endocrinology 152 556-567. (doi:10.1210/en.2010-1061)

Islam F, Sparkes C, Roodenrys S \& Astheimer L 2008 Short-term changes in endogenous estrogen levels and consumption of soy isoflavones affect working and verbal memory in young adult females. Nutritional Neuroscience 11 251-262. (doi:10.1179/1476830 08X301612) 
Jin Y, Duan L, Chen M, Penning TM \& Kloosterboer HJ 2012 Metabolism of the synthetic progestogen norethynodrel by human ketosteroid reductases of the aldo-keto reductase superfamily. Journal of Steroid Biochemistry and Molecular Biology 129 139-144. (doi:10.1016/j.jsbmb.2011.12.002)

Jodhka PK, Kaur P, Underwood W, Lydon JP \& Singh M 2009 The differences in neuroprotective efficacy of progesterone and medroxyprogesterone acetate correlate with their effects on brain-derived neurotrophic factor expression. Endocrinology 150 3162-3168. (doi:10.1210/en.2008-1247)

Jones BL, Whiting PJ \& Henderson LP 2006 Mechanisms of anabolic androgenic steroid inhibition of mammalian epsilon-subunitcontaining GABAA receptors. Journal of Physiology 573 571-593. (doi:10.1113/jphysiol.2006.106534)

Jung-Testas I, Schumacher M, Robel P \& Baulieu EE 1996 Demonstration of progesterone receptors in rat Schwann cells. Journal of Steroid Biochemistry and Molecular Biology 58 77-82. (doi:10.1016/ 0960-0760(96)00009-X)

Khanim F, Davies N, Veliça P, Hayden R, Ride J, Pararasa C, Chong MG, Gunther U, Veerapen N, Winn P, et al. 2014 Selective AKR1C3 inhibitors do not recapitulate the anti-leukaemic activities of the pan-AKR1C inhibitor medroxyprogesterone acetate. British Journal of Cancer 110 1506-1516. (doi:10.1038/bjc.2014.83)

Khanna M, Qin KN, Wang RW \& Cheng KC 1995 Substrate specificity, gene structure, and tissue-specific distribution of multiple human 3 alpha-hydroxysteroid dehydrogenases. Journal of Biological Chemistry 270 20162-20168. (doi:10.1074/jbc.270.34.20162)

King SR 2013 Neurosteroids and the Nervous System. New York, NY: Springer New York. (doi:10.1007/978-1-4614-5559-2)

Koubovec D, Ronacher K, Stubsrud E, Louw A \& Hapgood JP 2005 Synthetic progestins used in HRT have different glucocorticoid agonist properties. Molecular and Cellular Endocrinology 242 23-32. (doi:10.1016/j.mce.2005.07.001)

Krattenmacher R 2000 Drospirenone: pharmacology and pharmacokinetics of a unique progestogen. Contraception 62 29-38. (doi:10.1016/S0010-7824(00)00133-5)

Kroupova HK, Trubiroha A, Lorenz C, Contardo-Jara V, Lutz I, Grabic R, Kocour M \& Kloas W 2014 The progestin levonorgestrel disrupts gonadotropin expression and sex steroid levels in pubertal roach (Rutilus rutilus). Aquatic Toxicology 154 154-162. (doi:10.1016/j. aquatox.2014.05.008)

Kuhl H 2005 Pharmacology of estrogens and progestogens: influence of different routes of administration. Climacteric 8 3-63. (doi:10.1080/13697130500148875)

Lambert JJ, Belelli D, Peden DR, Vardy AW \& Peters JA 2003 Neurosteroid modulation of GABAA receptors. Progress in Neurobiology 71 67-80. (doi:10.1016/j.pneurobio.2003.09.001)

Larrea F, Vilchis F, Chávez B, Pérez AE, Garza-Flores J \& PérezPalacios G 1987 The metabolism of 19-nor contraceptive progestins modulates their biological activity at the neuroendocrine level. Journal of Steroid Biochemistry 27 657-663. (doi:10.1016/00224731(87)90134-8)

Larrea F, García-Becerra R, Lemus AE, García GA, Pérez-Palacios G, Jackson KJ, Coleman KM, Dace R, Smith CL \& Cooney AJ 2001 A-ring reduced metabolites of 19-nor synthetic progestins as subtype selective agonists for ER alpha. Endocrinology 142 3791-3799. (doi:10.1210/en.142.9.3791)

LeBlanc ES \& Laws A 1999 Benefits and risks of third-generation oral contraceptives. Journal of General Internal Medicine 14 625-632. (doi:10.1046/j.1525-1497.1999.08108.x)

Lello S 2010 Nomegestrol acetate: pharmacology, safety profile and therapeutic efficacy. Drugs 70 541-559. (doi:10.2165/11532130000000000-00000)

Lemus AE, Enríquez J, García GA, Grillasca I \& Pérez-Palacios G 1997 $5 \alpha$-Reduction of norethisterone enhances its binding affinity for androgen receptors but diminishes its androgenic potency. Journal of
Steroid Biochemistry and Molecular Biology 60 121-129. (doi:10.1016/ S0960-0760(96)00172-0)

Lenzi E, Pluchino N, Begliuomini S, Ninni F, Freschi L, Centofanti M, Casarosa E, Luisi S, Valentino V, Luisi M, et al. 2008 Effects of nomegestrol acetate administration on central and peripheral beta-endorphin and allopregnanolone in ovx rats. Journal of Steroid Biochemistry and Molecular Biology 110 67-75. (doi:10.1016/ j.jsbmb.2008.02.002)

Lenzi E, Pluchino N, Begliuomini S, Casarosa E, Merlini S, Giannini A, Luisi M, Kumar N, Sitruk-Ware R \& Genazzani AR 2009 Central modifications of allopregnanolone and beta-endorphin following subcutaneous administration of Nestorone. Journal of Steroid Biochemistry and Molecular Biology 116 15-20. (doi:10.1016/ j.jsbmb.2009.04.004)

Liang Y-Q, Huang G-Y, Liu S-S, Zhao J-L, Yang Y-Y, Chen X-W, Tian F, Jiang Y-X \& Ying G-G 2015a Long-term exposure to environmentally relevant concentrations of progesterone and norgestrel affects sex differentiation in zebrafish (Danio rerio). Aquatic Toxicology 160 172-179. (doi:10.1016/j.aquatox.2015.01.006)

Liang Y-Q, Huang G-Y, Ying G-G, Liu S-S, Jiang Y-X, Liu S \& Peng F-J $2015 b$ A time-course transcriptional kinetics of the hypothalamicpituitary-gonadal and hypothalamic-pituitary-adrenal axes in zebrafish eleutheroembryos after exposure to norgestrel. Environmental Toxicology and Chemistry 34 112-119. (doi:10.1002/etc.2766)

Liang Y-Q, Huang G-Y, Ying G-G, Liu S-S, Jiang Y-X \& Liu S 2015 c Progesterone and norgestrel alter transcriptional expression of genes along the hypothalamic-pituitary-thyroid axis in zebrafish embryos-larvae. Comparative Biochemistry and Physiology. Toxicology \& Pharmacology 167 101-107. (doi:10.1016/j.cbpc.2014.09.007)

Liu L, Zhao L, She H, Chen S, Wang JM, Wong C, McClure K, Sitruk-Ware R \& Brinton RD 2010 Clinically relevant progestins regulate neurogenic and neuroprotective responses in vitro and in vivo. Endocrinology 151 5782-5794. (doi:10.1210/en.2010-0005)

Liu A, Margaill I, Zhang S, Labombarda F, Coqueran B, Delespierre B, Liere P, Marchand-Leroux C, O'Malley BW, Lydon JP, et al. 2012 Progesterone receptors: a key for neuroprotection in experimental stroke. Endocrinology 153 3747-3757. (doi:10.1210/en.2012-1138)

Lorenz C, Contardo-Jara V, Trubiroha A, Krüger A, Viehmann V, Wiegand C, Pflugmacher S, Nützmann G, Lutz I \& Kloas W 2011 a The synthetic gestagen Levonorgestrel disrupts sexual development in Xenopus laevis by affecting gene expression of pituitary gonadotropins and gonadal steroidogenic enzymes. Toxicological Sciences 124 311-319. (doi:10.1093/toxsci/kfr241)

Lorenz C, Contardo-Jara V, Pflugmacher S, Wiegand C, Nützmann G, Lutz I \& Kloas W $2011 b$ The synthetic gestagen levonorgestrel impairs metamorphosis in Xenopus laevis by disruption of the thyroid system. Toxicological Sciences 123 94-102. (doi:10.1093/ toxsci/kfr159)

Luquin S, Naftolin F \& Garcia-Segura LM 1993 Natural fluctuation and gonadal hormone regulation of astrocyte immunoreactivity in dentate gyrus. Journal of Neurobiology 24 913-924. (doi:10.1002/ neu.480240705)

Maki PM \& Sundermann E 2009 Hormone therapy and cognitive function. Human Reproduction Update 15 667-681. (doi:10.1093/ humupd/dmp022)

Markov G, Bonneton F \& Laudet V 2010 Nuclear receptors. In Nuclear Receptors Current Concepts and Future Challenges, pp 15-29. Eds CM Bunce \& MJ Campbell. Dordrecht: Springer Netherlands.

Marra C, Gainotti G, Fadda L, Perri R, Lacidogna G, Scaricamazza E, Piccininni C \& Quaranta D 2015 Usefulness of an integrated analysis of different memory tasks to predict the progression from mild cognitive impairment to Alzheimer's disease: the Episodic Memory Score (EMS). Journal of Alzheimer's Disease 50 61-70. (doi:10.3233/ JAD-150613)

McEwen BS \& Woolley CS 1993 Estradiol and progesterone regulate neuronal structure and synaptic connectivity in adult as well as 
developing brain. Experimental Gerontology 29 431-436. (doi:10.1016/0531-5565(94)90022-1)

McIntyre KL, Porter DM \& Henderson LP 2002 Anabolic androgenic steroids induce age-, sex-, and dose-dependent changes in GABA(A) receptor subunit mRNAs in the mouse forebrain. Neuropharmacology 43 634-645. (doi:10.1016/S0028-3908(02)00154-5)

McLeod DG 1993 Antiandrogenic drugs. Cancer 71 1046-1049. (doi:10.1002/1097-0142(19930201)71:3+<1046::aidcncr2820711424>3.0.co;2-m)

Melcangi RC, Cavarretta ITR, Ballabio M, Leonelli E, Schenone A, Azcoitia I, Miguel Garcia-Segura L \& Magnaghi V 2005 Peripheral nerves: a target for the action of neuroactive steroids Brain Research. Brain Research Reviews 48 328-338. (doi:10.1016/ j.brainresrev.2004.12.021)

Melcangi RC \& Garcia-Segura LM 2010 Sex-specific therapeutic strategies based on neuroactive steroids: in search for innovative tools for neuroprotection. Hormones and Behavior 57 2-11. (doi:10.1016/ j.yhbeh.2009.06.001)

Melcangi RC, Garcia-Segura LM \& Mensah-Nyagan AG 2008 Neuroactive steroids: state of the art and new perspectives. Cellular and Molecular Life Sciences 65 777-797. (doi:10.1007/ s00018-007-7403-5)

Melcangi RC, Giatti S, Calabrese D, Pesaresi M, Cermenati G, Mitro N, Viviani B, Garcia-Segura LM \& Caruso D 2014 Levels and actions of progesterone and its metabolites in the nervous system during physiological and pathological conditions. Progress in Neurobiology 113 56-69. (doi:10.1016/j.pneurobio.2013.07.006)

Melcangi RC, Giatti S \& Garcia-Segura LM 2015 Levels and actions of neuroactive steroids in the nervous system under physiological and pathological conditions: sex-specific features. Neuroscience and Biobehavioral Reviews 67 25-40. (doi:10.1016/j. newbiorev.2015.09.023)

Meyer M, Gonzalez Deniselle MC, Garay L, Sitruk-Ware R, Guennoun R, Schumacher M \& De Nicola AF 2015 The progesterone receptor agonist Nestorone holds back proinflammatory mediators and neuropathology in the wobbler mouse model of motoneuron degeneration. Neuroscience 308 51-63. (doi:10.1016/j. neuroscience.2015.09.007)

Micevych P \& Sinchak K 2008 Synthesis and function of hypothalamic neuroprogesterone in reproduction. Endocrinology 149 2739-2742. (doi:10.1210/en.2008-0011)

Mihalik JP, Ondrak KS, Guskiewicz KM \& McMurray RG 2009 The effects of menstrual cycle phase on clinical measures of concussion in healthy college-aged females. Journal of Science and Medicine in Sport 12 383-387. (doi:10.1016/j.jsams.2008.05.003)

Moralí G, Lemus AE, Munguía R, García GA, Grillasca I \& Pérez-Palacios G 2002 Hormone-like behavioral effects of levonorgestrel and its metabolites in the male rat. Pharmacology Biochemistry and Behavior 73 951-961. (doi:10.1016/S0091-3057(02)00946-2)

Mordecai KL, Rubin LH \& Maki PM 2008 Effects of menstrual cycle phase and oral contraceptive use on verbal memory. Hormones and Behavior 54 286-293. (doi:10.1016/j.yhbeh.2008.03.006)

Muhn P, Fuhrmann U, Fritzemeier KH, Krattenmacher R \& Schillinger E 1995 Drospirenone: a novel progestogen with antimineralocorticoid and antiandrogenic activity. Annals of the New York Academy of Sciences 761 311-335. (doi:10.1111/j.1749-6632.1995.tb31386.x)

Murphy DD \& Segal M 2000 Progesterone prevents estradiol-induced dendritic spine formation in cultured hippocampal neurons. Neuroendocrinology 72 133-143. (doi:10.1159/000054580)

Nielsen SE, Ertman N, Lakhani YS \& Cahill L 2011 Hormonal contraception usage is associated with altered memory for an emotional story. Neurobiology of Learning and Memory 96 378-384. (doi:10.1016/j.nlm.2011.06.013)

Nilsen J \& Brinton RD 2002 Impact of progestins on estradiol potentiation of the glutamate calcium response. Neuroreport $\mathbf{1 3}$ 825-830. (doi:10.1097/00001756-200205070-00018)
Nilsen J \& Brinton RD 2003 Divergent impact of progesterone and medroxyprogesterone acetate (Provera) on nuclear mitogen-activated protein kinase signaling. PNAS 100 10506-10511. (doi:10.1073/ pnas.1334098100)

Nilsson B \& von Schoultz B 1989 Binding of levonorgestrel, norethisterone and desogestrel to human sex hormone binding globulin and influence on free testosterone levels. Gynecologic and Obstetric Investigation 27 151-154. (doi:10.1159/000293644)

Oelkers W 2004 Drospirenone, a progestogen with antimineralocorticoid properties: a short review. Molecular and Cellular Endocrinology 217 255-261. (doi:10.1016/j.mce.2003.10.030)

Oelkers W, Berger V, Bolik A, Bähr V, Hazard B, Beier S, Elger W \& Heithecker A 1991 Dihydrospirorenone, a new progestogen with antimineralocorticoid activity: effects on ovulation, electrolyte excretion, and the renin-aldosterone system in normal women. Journal of Clinical Endocrinology and Metabolism 73 837-842. (doi:10.1210/jcem-73-4-837)

Olbrich M, Weigl K, Kahler E \& Mihara K 2016 Dydrogesterone metabolism in human liver by aldo-keto reductases and cytochrome P450 enzymes. Xenobiotica 8254 1-7. (doi:10.3109/00498254.2015. 1134852)

Pang Y, Dong J \& Thomas P 2013 Characterization, neurosteroid binding and brain distribution of human membrane progesterone receptors $\delta$ and \{epsilon\} (mPR $\delta$ and $\mathrm{mPR}\{$ epsilon\}) and mPR $\delta$ involvement in neurosteroid inhibition of apoptosis. Endocrinology 154 283-295. (doi:10.1210/en.2012-1772)

Paoletti AM, Lello S, Fratta S, Orrù M, Ranuzzi F, Sogliano C, Concas A, Biggio G \& Melis GB 2004 Psychological effect of the oral contraceptive formulation containing $3 \mathrm{mg}$ of drospirenone plus 30 microg of ethinyl estradiol. Fertility and Sterility 81 645-651. (doi:10.1016/j.fertnstert.2003.08.030)

Pasapera AM, Gutierrez-Sagal R, Herrera J, Galicia-Canales N, Garcia de la Mora G \& Ulloa-Aguirre A 2002 Norethisterone is bioconverted to oestrogenic compounds that activate both the oestrogen receptor alpha and oestrogen receptor beta in vitro. European Journal of Pharmacology 452 347-355. (doi:10.1016/S0014-2999(02)02337-3)

Pasqualini JR 1996 Progestins: present and future. Journal of Steroid Biochemistry and Molecular Biology 5-6 357-363. (doi:10.1016/ S0960-0760(96)00183-5)

Pawlak M, Lefebvre P \& Staels B 2012 General molecular biology and architecture of nuclear receptors. Current Topics in Medicinal Chemistry 12 486-504. (doi:10.2174/156802612799436641)

Penning TM, Burczynski ME, Jez JM, Hung CF, Lin HK, Ma H, Moore M, Palackal N \& Ratnam K 2000 Human 3alpha-hydroxysteroid dehydrogenase isoforms (AKR1C1-AKR1C4) of the aldo-keto reductase superfamily: functional plasticity and tissue distribution reveals roles in the inactivation and formation of male and female sex hormones. Biochemical Journal 351 67-77. (doi:10.1042/ bj3510067)

Penning TM, Chen M \& Jin Y 2015 Promiscuity and diversity in 3-ketosteroid reductases. Journal of Steroid Biochemistry and Molecular Biology 151 93-101. (doi:10.1016/j.jsbmb.2014.12.003)

Petersen LH, Hala D, Carty D, Cantu M, Martinović D \& Huggett DB 2015 Effects of progesterone and norethindrone on female fathead minnow (Pimephales promelas) steroidogenesis. Environmental Toxicology and Chemistry 34 379-390. (doi:10.1002/ etc.2816)

Philibert D, Bouchoux F, Degryse M, Lecaque D, Petit F \& Gaillard M 1999 The pharmacological profile of a novel norpregnance progestin (trimegestone). Gynecological Endocrinology 13 316-326. (doi:10.3109/09513599909167574)

Pletzer BA \& Kerschbaum HH 201450 years of hormonal contraception-time to find out, what it does to our brain. Frontiers in Neuroscience 8 256. (doi:10.3389/fnins.2014.00256)

Pletzer B, Kronbichler M \& Kerschbaum H 2015 Differential effects of androgenic and anti-androgenic progestins on fusiform and frontal

Published by Bioscientifica Ltd 
gray matter volume and face recognition performance. Brain Research 1596 108-115. (doi:10.1016/j.brainres.2014.11.025)

Pluchino N, Lenzi E, Casarosa E, Cela V, Begliuomini S, Ninni F, Freschi L, Luisi S \& Genazzani AR 2008 Dydrogesterone increases allopregnanolone in selected brain areas and in serum of female rats. Fertility and Sterility 89 1384-1389. (doi:10.1016/j. fertnstert.2007.03.077)

Pluchino N, Lenzi E, Merlini S, Giannini A, Cubeddu A, Casarosa E, Begliuomini S, Luisi M, Cela V \& Genazzani AR 2009 Selective effect of chlormadinone acetate on brain allopregnanolone and opioids content. Contraception 80 53-62. (doi:10.1016/j.contraception.2009.01.005)

Porcu P, Mostallino MC, Sogliano C, Santoru F, Berretti R \& Concas A 2012 Long-term administration with levonorgestrel decreases allopregnanolone levels and alters $\mathrm{GABA}(\mathrm{A})$ receptor subunit expression and anxiety-like behavior. Pharmacology, Biochemistry, and Behavior 102 366-372. (doi:10.1016/j.pbb.2012.05.011)

Porcu P, Barron AM, Frye CA, Walf AA, Yang S-Y, He X-Y, Morrow AL, Panzica GC \& Melcangi RC 2016 Neurosteroidogenesis today: novel targets for neuroactive steroid synthesis and action and their relevance for translational research. Journal of Neuroendocrinology 2812351. (doi:10.1111/jne.12351)

Rabe T, Luxembourg B, Ludwig M, Dinger J, Bauersachs R, Rott H, Mueck AO \& Albring C 2012 Kontrazeption \& Thrombophilie - Eine stellungnahme der deutschen gesellschaft für gynäkologische endokrinologie und fortpflanzungsmedizin (DGGEF) e.V. und des berufsverbands für frauenärzte (BVF) e.V. Journal Fur Reproduktionsmedizin Und Endokrinologie 9 20-46.

Rapkin AJ, Morgan M, Sogliano C, Biggio G \& Concas A 2006 Decreased neuroactive steroids induced by combined oral contraceptive pills are not associated with mood changes. Fertility and Sterility $\mathbf{8 5}$ 1371-1378. (doi:10.1016/j.fertnstert.2005.10.031)

Raudrant D \& Rabe T 2003 Progestogens with antiandrogenic properties. Drugs 63 463-492. (doi:10.2165/00003495-200363050-00003)

Rettberg JR, Yao J \& Brinton RD 2014 Estrogen: a master regulator of bioenergetic systems in the brain and body. Frontiers in Neuroendocrinology 35 8-30. (doi:10.1016/j.yfrne.2013.08.001)

Reyna-Neyra A, Camacho-Arroyo I, Ferrera P \& Arias C 2002 Estradiol and progesterone modify microtubule associated protein 2 content in the rat hippocampus. Brain Research Bulletin 58 607-612. (doi:10.1016/S0361-9230(02)00829-8)

Rižner TL \& Penning TM 2014 Role of aldo-keto reductase family 1 (AKR1) enzymes in human steroid metabolism. Steroids 79 49-63. (doi:10.1016/j.steroids.2013.10.012)

Rižner TL, Brožič P, Doucette C, Turek-Etienne T, Müller-Vieira U, Sonneveld E, van der Burg B, Böcker C \& Husen B 2011 Selectivity and potency of the retroprogesterone dydrogesterone in vitro. Steroids 76 607-615. (doi:10.1016/j.steroids.2011.02.043)

Roglio I, Giatti S, Pesaresi M, Bianchi R, Cavaletti G, Lauria G, Garcia-Segura LM \& Melcangi RC 2008 Neuroactive steroids and peripheral neuropathy. Brain Research Reviews 57 460-469. (doi:10.1016/j.brainresrev.2007.04.010)

Rosenberg L \& Park S 2002 Verbal and spatial functions across the menstrual cycle in healthy young women. Psychoneuroendocrinology 27 835-841. (doi:10.1016/S0306-4530(01)00083-X)

Rossouw JE, Anderson GL, Prentice RL, LaCroix AZ, Kooperberg C, Stefanick ML, Jackson RD, Beresford SAA, Howard B V, Johnson KC, et al. 2002 Risks and benefits of estrogen plus progestin in healthy postmenopausal women: principal results from the Women's Health Initiative randomized controlled trial. JAMA 288 321-333. (doi:10.1001/jama.288.3.321)

Saletu B, Anderer P, Saletu-Zyhlarz GM, Gruber D, Metka M \& Huber J 2005 Identifying target regions for vigilance improvement under hormone replacement therapy in postmenopausal syndrome patients by means of electroencephalographic tomography (LORETA). Psychopharmacology 178 389-399. (doi:10.1007/s00213-004-2029-x)
Santillán R, Pérez-Palacios G, Reyes M, Damián-Matsumura P, García GA, Grillasca I \& Lemus AE 2001 Assessment of the oestrogenic activity of the contraceptive progestin levonorgestrel and its non-phenolic metabolites. European Journal of Pharmacology 427 167-174. (doi:10.1016/S0014-2999(01)01263-8)

Santoru F, Berretti R, Locci A, Porcu P \& Concas A 2014 Decreased allopregnanolone induced by hormonal contraceptives is associated with a reduction in social behavior and sexual motivation in female rats. Psychopharmacology 231 3351-3364. (doi:10.1007/s00213-0143539-9)

Sassoè-Pognetto M, Follesa P, Panzanelli P, Perazzini A-Z, Porcu P, Sogliano C, Cherchi C \& Concas A 2007 Fluctuations in brain concentrations of neurosteroids are not associated to changes in gephyrin levels. Brain Research 1169 1-8. (doi:10.1016/j. brainres.2007.06.057)

Sator MO, Wieser F, Gruber DM, Joura EA \& Huber JC 1999 Trends in the prescription of psychotropic drugs and hormone substitutes in Austria. Wiener Klinische Wochenschrift 111 402-405. (doi:10.1016/ j.brainres.2007.06.057)

Schindler AE, Campagnoli C, Druckmann R, Huber J, Pasqualini JR, Schweppe KW \& Thijssen JHH 2003 Classification and pharmacology of progestins. Maturitas 46 S7-S16. (doi:10.1016/j. maturitas.2003.09.014)

Schneider LS \& Farlow M 1997 Combined tacrine and estrogen replacement therapy in patients with Alzheimer's disease. Annals of the New York Academy of Sciences 826 317-322. (doi:10.1111/j.1749-6632.1997.tb48482.x)

Schumacher M, Mattern C, Ghoumari A, Oudinet JP, Liere P, Labombarda F, Sitruk-Ware R, De Nicola AF \& Guennoun R 2014 Revisiting the roles of progesterone and allopregnanolone in the nervous system: resurgence of the progesterone receptors. Progress in Neurobiology 113 6-39. (doi:10.1016/j. pneurobio.2013.09.004)

Schumacher M, Denier C, Oudinet J-P, Adams D \& Guennoun R 2016 Progesterone neuroprotection: the background of clinical trial failure. Journal of Steroid Biochemistry and Molecular Biology 160 53-66. (doi:10.1016/j.jsbmb.2015.11.010)

Shetty KT \& Gaitonde BB 1980 Effect of the chronic administration of ethinyl estradiol and norgestrel on biogenic amine(s) level and monoamine oxidase enzyme activity in rat brain. Biochemical Pharmacology 29 821-825. (doi:10.1016/00062952(80)90563-8)

Shumaker SA, Legault C, Rapp SR, Thal L, Wallace RB, Ockene JK, Hendrix SL, Jones BN, Assaf AR, Jackson RD, et al. 2003 Estrogen plus progestin and the incidence of dementia and mild cognitive impairment in postmenopausal women: the Women's Health Initiative Memory Study: a randomized controlled trial. JAMA 289 2651-2662. (doi:10.1001/jama.289.20.2663)

Simone J, Bogue EA, Bhatti DL, Day LE, Farr NA, Grossman AM \& Holmes P V 2015 Ethinyl estradiol and levonorgestrel alter cognition and anxiety in rats concurrent with a decrease in tyrosine hydroxylase expression in the locus coeruleus and brain-derived neurotrophic factor expression in the hippocampus. Psychoneuroendocrinology 62 265-278. (doi:10.1016/j.psyneuen.2015.08.015)

Singh M 2007 Progestins and neuroprotection: are all progestins created equal? Minerva Endocrinologica 32 95-102.

Singh M \& Su C 2013 Progesterone and neuroprotection. Hormones and Behavior 63 284-290. (doi:10.1016/j.yhbeh.2012.06.003)

Singh M, Su C \& Ng S 2013 Non-genomic mechanisms of progesterone action in the brain. Frontiers in Neuroscience 7 1-7.

Sitruk-Ware L 2000 Progestins and Antiprogestins in Clinical Practice. New York: Marcel Dekker.

Sitruk-Ware R 2002 Progestogens in hormonal replacement therapy: new molecules, risks, and benefits. Menopause 9 6-15. (doi:10.1097/00042192-200201000-00003) http://jme.endocrinology-journals.org

DOI: 10.1530/JME-16-0061
๑ 2016 Society for Endocrinology Printed in Great Britain 
Sitruk-Ware R 2004 Pharmacological profile of progestins. Maturitas 47 277-283. (doi:10.1016/j.maturitas.2004.01.001)

Sitruk-Ware R \& Nath A 2010 The use of newer progestins for contraception. Contraception 82 410-417. (doi:10.1016/ j.contraception.2010.04.004)

Skinner DC, Evans NP, Delaleu B, Goodman RL, Bouchard P \& Caraty A 1998 The negative feedback actions of progesterone on gonadotropinreleasing hormone secretion are transduced by the classical progesterone receptor. PNAS 95 10978-10983. (doi:10.1073/pnas.95.18.10978)

Smith YR, Love T, Persad CC, Tkaczyk A, Nichols TE \& Zubieta J-K 2006 Impact of combined estradiol and norethindrone therapy on visuospatial working memory assessed by functional magnetic resonance imaging. Journal of Clinical Endocrinology and Metabolism 91 4476-4481. (doi:10.1210/jc.2006-0907)

Sobey W 2008 The handbook of contraception: a guide for practical management. Journal of Midwifery 53 99-100. (doi:10.1016/ j.jmwh.2007.08.021)

Stanczyk FZ 2003 All progestins are not created equal. Steroids $\mathbf{6 8}$ 879-890. (doi:10.1016/j.steroids.2003.08.003)

Stanczyk FZ \& Bhavnani BR 2014 Use of medroxyprogesterone acetate for hormone therapy in postmenopausal women: is it safe? Journal of Steroid Biochemistry and Molecular Biology 142 30-38. (doi:10.1016/j. jsbmb.2013.11.011)

Stanczyk FZ \& Bhavnani BR 2015 Reprint of 'Use of medroxyprogesterone acetate for hormone therapy in postmenopausal women: is it safe?'. Journal of Steroid Biochemistry and Molecular Biology 153 151-159. (doi:10.1016/j.jsbmb.2015.08.013)

Stanczyk FZ, Hapgood JP, Winer S \& Mishell DR 2013 Progestogens used in postmenopausal hormone therapy: differences in their pharmacological properties, intracellular actions, and clinical effects. Endocrine Reviews 34 171-208. (doi:10.1210/er.2012-1008)

Steckelbroeck S, Jin Y, Oyesanmi B, Kloosterboer HJ \& Penning TM 2004 Tibolone is metabolized by the 3alpha/3beta-hydroxysteroid dehydrogenase activities of the four human isozymes of the aldo-keto reductase 1C subfamily: inversion of stereospecificity with a delta5(10)-3-ketosteroid. Molecular Pharmacology 66 1702-1711. (doi:10.1124/mol.104.004515)

Stuenkel CA, Davis SR, Gompel A, Lumsden MA, Murad MH, Pinkerton JV \& Santen RJ 2015 Treatment of symptoms of the menopause: an Endocrine Society Clinical Practice Guideline. Journal of Clinical Endocrinology and Metabolism 100 3975-4011. (doi:10.1210/jc.2015-2236)

Szot P, Wilkinson CW, White SS, Leverenz JB, Greenup JL, Colasurdo EA, Peskind ER \& Raskind MA 2004 Chronic cortisol suppresses pituitary and hypothalamic peptide message expression in pigtailed macaques. Neuroscience 126 241-246. (doi:10.1016/ j.neuroscience.2004.03.030)

Tepper R, Neri A, Kaufman H, Schoenfeld A \& Ovadia J 1987 Menopausal hot flushes and plasma beta-endorphins. Obstetrics and Gynecology 70 150-152.

Thomas P 2008 Characteristics of membrane progestin receptor alpha (mPRalpha) and progesterone membrane receptor component 1 (PGMRC1) and their roles in mediating rapid progestin actions. Frontiers in Neuroendocrinology 29 292-312. (doi:10.1016/j.yfrne.2008.01.001)

Thomas P, Pang Y, Dong J, Groenen P, Kelder J, De Vlieg J, Zhu Y \& Tubbs C 2007 Steroid and G protein binding characteristics of the seatrout and human progestin membrane receptor $\alpha$ subtypes and their evolutionary origins. Endocrinology 148 705-718. (doi:10.1210/ en.2006-0974)

Toffoletto S, Lanzenberger R, Gingnell M, Sundström-Poromaa I \& Comasco E 2014 Emotional and cognitive functional imaging of estrogen and progesterone effects in the female human brain: a systematic review. Psychoneuroendocrinology 50 28-52. (doi:10.1016/ j.psyneuen.2014.07.025)

Tsutsui K 2008 Progesterone biosynthesis and action in the developing neuron. Endocrinology 149 2757-2761. (doi:10.1210/en.2007-1592)

Tsutsui K, Ukena K, Sakamoto H, Okuyama S-I \& Haraguchi S 2011 Biosynthesis, mode of action, and functional significance of neurosteroids in the purkinje cell. Frontiers in Endocrinology 261. (doi:10.3389/fendo.2011.00061)

Van Diepen HA, Lam TW \& Kuil CW 2011 Nomegestrol acetate: steroid receptor transactivation profile in Chinese hamster ovary cells and ovulation inhibition in rat and monkey. Contraception 84 199-204. (doi:10.1016/j.contraception.2010.11.017)

Wagner KD \& Berenson AB 1994 Norplant-associated major depression and panic disorder. Journal of Clinical Psychiatry 55 478-480.

Walf AA, Rhodes ME \& Frye CA 2006 Ovarian steroids enhance object recognition in naturally cycling and ovariectomized, hormone-primed rats. Neurobiology of Learning and Memory 86 35-46. (doi:10.1016/j.nlm.2006.01.004)

Wang M, He Y, Eisenman LN, Fields C, Zeng C-M, Mathews J, Benz A, Fu T, Zorumski E, Steinbach JH, et al. 2002 3beta-hydroxypregnane steroids are pregnenolone sulfate-like $\mathrm{GABA}(\mathrm{A})$ receptor antagonists. Journal of Neuroscience 22 3366-3375.

Wang JM, Liu L, Irwin RW, Chen S \& Brinton RD 2008 Regenerative potential of allopregnanolone. Brain Research Reviews 57 398-409. (doi:10.1016/j.brainresrev.2007.08.010)

Wharton W, Hirshman E, Merritt P, Doyle L, Paris S \& Gleason C 2008 Oral contraceptives and androgenicity: influences on visuospatial task performance in younger individuals. Experimental and Clinical Psychopharmacology 16 156-164. (doi:10.1037/1064-1297.16.2.156)

Wiegratz I, Sänger N \& Kuhl H 2002 Formation of 7 alpha-methyl-ethinyl estradiol during treatment with tibolone. Menopause 9 293-295. (doi:10.1097/00042192-200207000-00011)

Yao J, Irwin R, Chen S, Hamilton R, Cadenas E \& Brinton RD 2012 Ovarian hormone loss induces bioenergetic deficits and mitochondrial $\beta$-amyloid. Neurobiology of Aging 33 1507-1521. (doi:10.1016/j.neurobiolaging.2011.03.001)

Zacharia LC, Jackson EK, Kloosterboer HJ, Imthurn B \& Dubey RK 2007 Conversion of tibolone to 7alpha-methyl-ethinyl estradiol using gas chromatography-mass spectrometry and liquid chromatographymass spectrometry: interpretation and clinical implications. Menopause 13 926-934. (doi:10.1097/01.gme.0000227331.49081.d7)

Zhao L, Morgan TE, Mao Z, Lin S, Cadenas E, Finch CE, Pike CJ, Mack WJ \& Brinton RD 2012 Continuous versus cyclic progesterone exposure differentially regulates hippocampal gene expression and functional profiles. PloS One 7 e31267. (doi:10.1371/journal.pone.0031267)

Zhao Y, Castiglioni S \& Fent K 2015a Synthetic progestins medroxyprogesterone acetate and dydrogesterone and their binary mixtures adversely affect reproduction and lead to histological and transcriptional alterations in zebrafish (Danio rerio). Environmental Science \& Technology 49 4636-4645. (doi:10.1021/es505575v)

Zhao Y, Castiglioni S \& Fent K $2015 b$ Environmental progestins progesterone and drospirenone alter the circadian rhythm network in zebrafish (Danio rerio). Environmental Science \& Technology 49 10155-10164. (doi:10.1021/acs.est.5b02226)

Zhu Y, Bond J \& Thomas P 2003 Identification, classification, and partial characterization of genes in humans and other vertebrates homologous to a fish membrane progestin receptor. PNAS $\mathbf{1 0 0}$ 2237-2242. (doi:10.1073/pnas.0436133100)

Zucchi S, Mirbahai L, Castiglioni S \& Fent K 2014 Transcriptional and physiological responses induced by binary mixtures of drospirenone and progesterone in zebrafish (Danio rerio). Environmental Science \& Technology 48 3523-3531. (doi:10.1021/es405584f)

Received in final form 17 May 2016

Accepted 22 June 2016

Accepted Preprint published online 23 June 2016 http://jme.endocrinology-journals.org

DOI: 10.1530/JME-16-0061
(C) 2016 Society for Endocrinology Printed in Great Britain
Published by Bioscientifica Ltd 